\title{
21. PALEOCENE AND EARLY EOCENE MICROFACIES, BENTHONIC FORAMINIFERA, AND PALEOBATHYMETRY OF DEEP SEA DRILLING PROJECT SITES 236 AND 237, WESTERN INDIAN OCEAN
}

\author{
Edith Vincent, Department of Geological Sciences, University of Southern California, Los Angeles, California \\ James M. Gibson, Texaco Inc., Los Angeles, California \\ and \\ Lélio Brun, Centre de Recherches de Boussens, Laboratoire Exploration ELF-RE, Saint Martory, France
}

\begin{abstract}
A significant and abrupt change in the sedimentary regime at Site 237 provides evidence for an early Tertiary subsidence of the Mascarene Plateau area in the western Indian Ocean. Between approximately 62 and 57 m.y.B.P. pelagic sediments were deposited at Site 237 in upper bathyal $(200-600 \mathrm{~m})$ depths with admixtures of slumped material from nearby shoals at a rate of about $68 \mathrm{~m} / \mathrm{m} . \mathrm{y}$. The sea floor began to sink in the late Paleocene (57-58 m.y.B.P.). Introduction of shallow-water material ceased and normal pelagic sedimentation proceeded, at a rate about six times slower, at lower bathyal $(600-2500 \mathrm{~m})$ depths. Deepening at Site 237 at this time permitted development of deep-water benthonic foraminiferal faunas similar to those at Site 236 to the north. A further decrease in the rate of sedimentation occurred near the end of the Paleocene and in early Eocene, from approximately 54 to 50 m.y.B.P. During that period of time an interval of nondeposition spanned the Paleocene/Eocene boundary at Site 236. The area at Site 237 has subsided approximately 2000 meters over the past 52 m.y.

This sequence of events on the Mascarene Plateau is similar to, and synchronous with, the subsidence history of the ChagosLaccadive Ridge to the east.
\end{abstract}

\section{INTRODUCTION}

The Mascarene Plateau, a major structural element of the Indian Ocean, forms the foundation for a series of islands and shallow banks that extend in a gentle northwest to south crescent across the western tropical Indian Ocean (Fisher et al., 1967). During Leg 24 of the Deep Sea Drilling Project, Glomar Challenger drilled two holes in the Mascarene Plateau area. Site 236, in 4500 meters of water, is located in the outermost foothills southwest of the Carlsberg Ridge, $270 \mathrm{~km}$ northeast of the Seychelles Islands, the northern termination of the Mascarene Plateau. Site 237 , in 1630 meters of water, was drilled in the saddle joining the granitic Seychelles Bank to the volcanic Saya de Malha Bank (Figure 1 and Table 1). The thickness of the Paleocene and lower Eocene section is 42 meters at Site 236 and about nine times greater ( 374 meters) at Site 237. Site 236 reached basement, whereas Site 237 was terminated before basement was reached for operational reasons.

The age of the foundation and the petrologic affinity of that part of the Mascarene Plateau located between Precambrian granitic Seychelles and volcanic Saya de Malha are a matter of controversy. Site 237 was drilled in this area to answer these questions and to establish the rate and continuity of subsidence of what was thought to be an extensive reef area on a massive igneous base. Drilling at Site 237 failed to determine the age and nature of the basement, but the thick early Tertiary sedimentary sequence recovered here provides clues to help elucidate the subsidence history of the area. No coralline section was penetrated and the area appears to have been a site of pelagic sedimentation since early Paleocene time. The purpose of this study was to gain information on the depositional environment and paleodepth on the Mascarene Plateau during the Paleocene and early Eocene. Thin sections from lithified oozes at Site 237 were examined for this purpose, as well as to complement the planktonic foraminiferal zonation established at this site based on the fauna extracted from the few soft horizons. Benthonic foraminiferal faunas extracted from these unlithified sediments at Sites 236 and 237 were also studied.

The Paleocene and lower Eocene sequence at Site 236, which underlies 263 meters of Quaternary to late Paleocene nannofossil chalk oozes, consists of nannofossil chalk with chert. It was continuously cored with a poor recovery. A good sediment/basement contact was obtained within Core 33 at 305 meters. The biostratigraphic age of the basal sediments is 56-58 m.y. old (Discoaster mohleri and P.4 zones) according to Berggren's (1972) scale; whereas the magnetic age of basement is 9 to 11 m.y. older (approximately magnetic anomaly 27, McKenzie and Sclater, 1971) according to the geomagnetic scale of Heirtzler et al. (1968). Two substantial stratigraphic gaps were found, one spanning the late Paleocene/early Eocene boundary and the other representing the entire middle Eocene. 


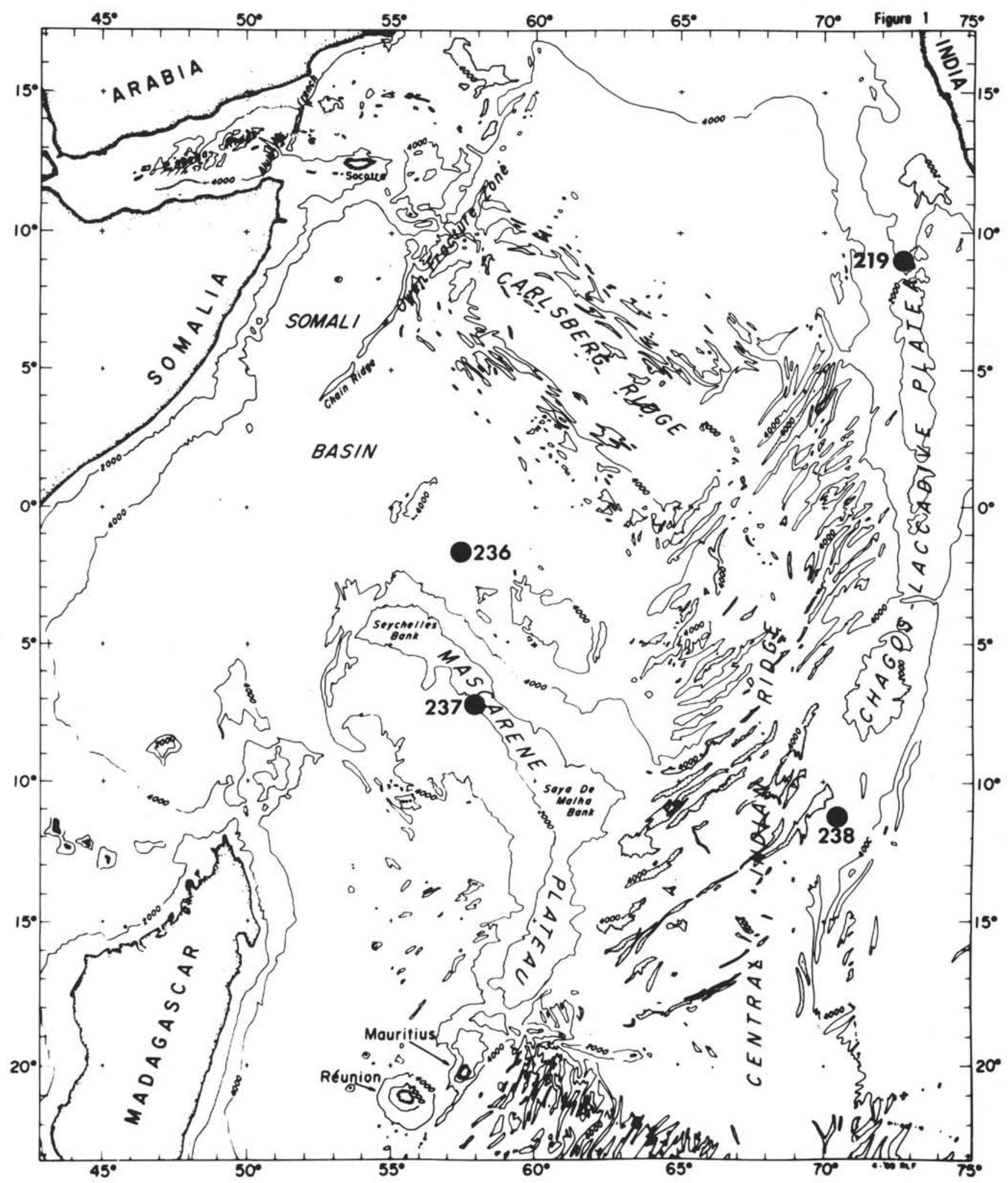

Figure 1. Location of DSDP sites on the Mascarene Plateau/Central Indian Ridge/Chagos-Laccadive Plateau complex. 
TABLE 1

Location of Sites Containing Paleocene and Lower Eocene Deposits Drilled on Leg 24

\begin{tabular}{lcccccc}
\hline & & & & \multicolumn{3}{c}{$\begin{array}{c}\text { Paleocene and Lower } \\
\text { Eocene Section }\end{array}$} \\
\cline { 5 - 7 } Site & Latitude & Longitude & $\begin{array}{c}\text { Water } \\
\text { Depth } \\
\text { (m) }\end{array}$ & $\begin{array}{c}\text { Thickness } \\
(\mathrm{m})\end{array}$ & Cores \\
\hline 236 & $1^{\circ} 40.62^{\prime} \mathrm{S}$ & $57^{\circ} 38.85^{\prime} \mathrm{E}$ & 4504 & 42 & $29-33$ \\
237 & $7^{\circ} 04.99^{\prime} \mathrm{S}$ & $58^{\circ} 07.48^{\prime} \mathrm{E}$ & 1640 & 374 & $35-67$ \\
\hline
\end{tabular}

The Paleocene and lower Eocene section at Site 237, which underlies 320 meters of Quaternary to middle Eocene nannofossil ooze, consists of partly silicified nannofossil chalk with chert, with some glauconitic horizons in the upper Paleocene. Coring, with poor recovery, was continuous in the upper part of that section down to a depth of 585 meters, and from that depth to hole bottom alternate joints were cored.

A summary of the Paleocene and early Eocene lithology, fossil zonations, age assignment, and sedimentation rates at both Sites 236 and 237 is presented in Figure 2.

\section{MICROFACIES}

Folk's (1962) classification was used to describe the microscopic features of 42 thin sections from the Paleocene and lower Eocene silicified nannofossil chalks (lithologic Units 3, 4, and 5) of Site 237 (Table 2 and Figure 3). The bulk of the rocks consists of sparse to packed biomicrite, often modified by recrystallization and silicification, with planktonic foraminifera as the main skeletal grain in the Paleocene sequence and radiolarians in the lower Eocene. Recrystallization is very pronounced in the lower 54 meters (below Core 65). The high planktonic/benthonic foraminiferal ratio clearly reflects a pelagic environmnent, planktonic species usually comprising $90 \%$ or more of the foraminiferal population with an increasing trend up section. Among subordinate biogenic grain types, sponge spicules occur commonly while echinoderm spines and molluscan fragments are rare. Chambers of the skeletal components are infilled either by microspar, spar, micrite, or chert. Radiolarians are often calcified. The various biogenic components are regularly distributed throughout the sediment, and evidence of bioturbation is not common. Fecal pellets were found in a few horizons. Small quartz grains and glauconite, which occurs as grains or occasionally as infilling of foraminiferal chambers, are present in the lower part of the section from 410 to 670 meters, with an abundance of $1 \%$ and $1 \%$ to $5 \%$, respectively.

The high degree of recrystallization precludes identification of the components of the matrix, which was probably composed of nannofossils as indicated by the smear-slide analyses. These show that nannofossils comprise $80 \%$ to $95 \%$ of the sediments above 516 meters; whereas below this level micarb, which may represent altered nannofossils, is the main contributor ( $80 \%$ to $95 \%$ ) (Figure 3).

Interbedded in the Paleocene pelagic deposits are several horizons of coarse material. These consist of packed biomicrite or biosparite with larger foraminifera (Discocyclina, Ranikothalia), calcareous algae (Archaeo- lithothamnium), and fragments of molluscs, echinoderms, and bryozoans. These horizons represent slumped shallowwater deposits, and their contact with the fine-grained rock in which they occur is sharp (Thiede, this volume, Figure 30).

Planktonic foraminifera were identified and several foraminiferal zonal boundaries were defined. The Morozovella pusilla-Morozovella angulata (P.3)/Morozovella uncinata-Turborotalia spiralis (P.2) boundary, which separates the late and early Paleocene, was placed within Core 61, Section 1, at the lowest occurrence of Morozovella angulata. The Planorotalites pseudomenardii (P.4)/Morozovella pusilla-Turborotalia spiralis (P.3) boundary could not be defined between Cores 45 , Section 2 and Core 54, Section 1, because of the co-occurrence in this interval of forms referable to Morozovella velascoensis and Morozovella laevigata (younger than P.3) and forms referable to Planorotalites compressa and Subbotina triloculinoides (older than P.4).

The position of the P.3/P.2 boundary at 574 meters in the section and of the Discoaster mohleri Zone/Heliolithus kleinpella Zone boundary at 403.5 meters, at 60 and 57.5 m.y.B.P., respectively (Berggren, 1972), permits the calculation of an average accumulation rate of $68.2 \mathrm{~m} / \mathrm{m} . \mathrm{y}$. for the sediments deposited between these two points in time (Figure 2). If it is assumed that approximately 100 meters of additional sediments are present between the bottom of Hole 237 and the igneous basement below them (this volume, Chapter 8) and that the accumulation rate of 68.2 $\mathrm{m} / \mathrm{m} . \mathrm{y}$. remained constant, then the age of the sediment/ basement contact is approximately 63 m.y.B.P. (early Paleocene).

\section{BENTHONIC FORAMINIFERA}

Benthonic foraminifera are very rare at both Sites 236 and 237, with the bulk of the coarse fraction $(>61 \mu)$ consisting of planktonic foraminifera or siliceous components (radiolarians, sponge spicules) or both. Preservation is generally fair, but, the lower part of the section at Site 237 (corresponding roughly to the P.1 to P.3 interval) is dominantly recrystallized.

We identified 134 species of benthonic foraminifera. Many of these were described and illustrated in classical works on the faunas of the Midway Group of the U. S. Gulf Coastal Plain (Plummer, 1926; Cushman, 1951; Kellough, $1959,1965)$ and the Velasco Formation of the Tampico Embayment in Mexico (Cushman, 1925, 1926; White, 1928, 1929; Cushman and Renz, 1946). The distribution of species at Sites 236 and 237 is shown in Tables 3 and 4. Species diversity, which may reflect bathymetry (Gibson and Buzas, 1973), was not investigated because the small volume of available samples and the low number of benthonic specimens precluded a statistically valid study.

\section{PALEOBATHYMETRY}

\section{Basis for Paleobathymetric Interpretations}

A number of faunal relationships provide good evidence of depositional environment (Bandy, 1960; Bandy and Arnal, 1960). The relative abundance of planktonic foraminifera in bottom sediments increases offshore (Grimsdale and Morkhoven, 1955; Bandy and Arnal, 1960). Planktonic 


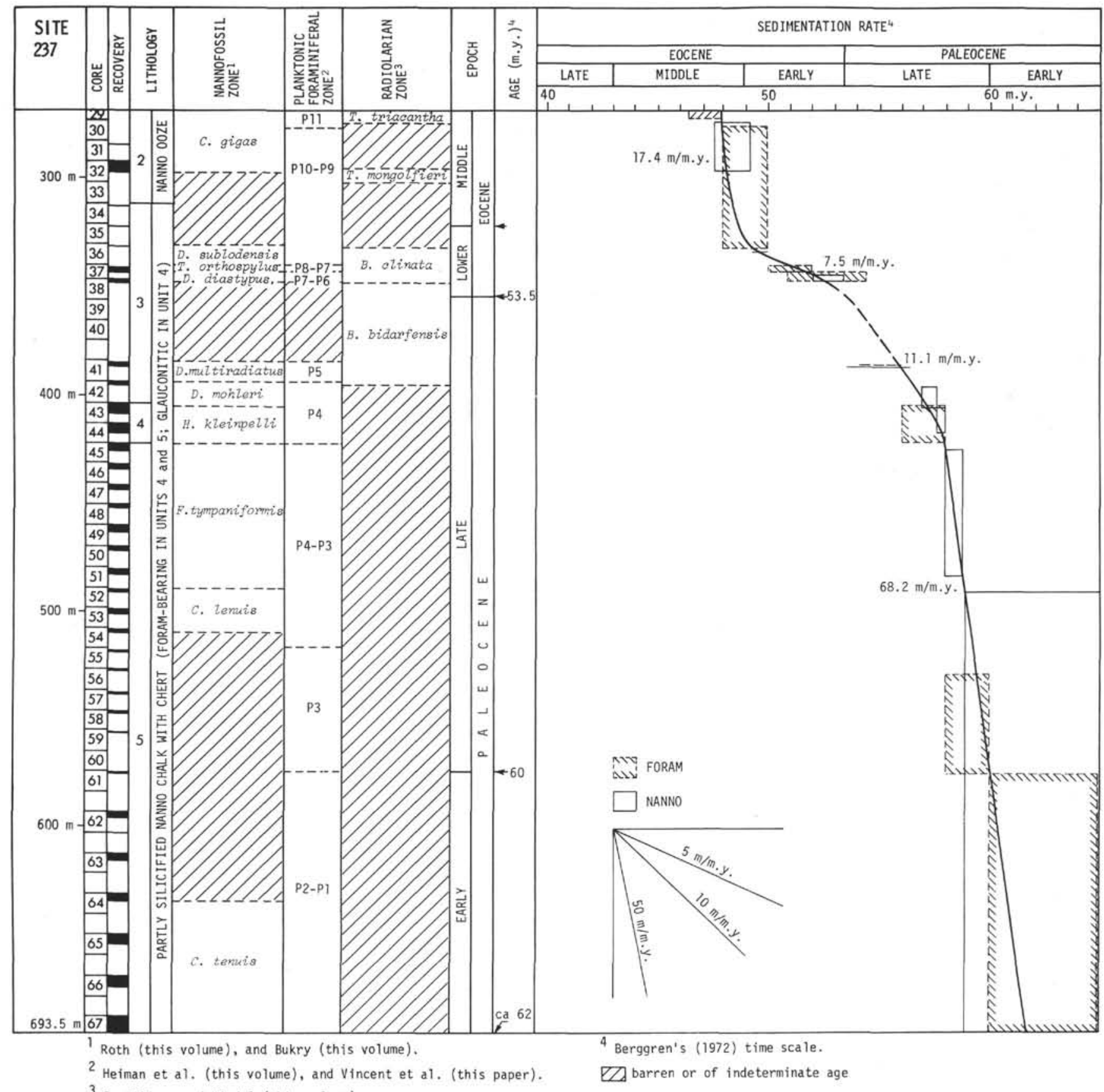

${ }^{3}$ Sanfilippo and Riedel (this volume).

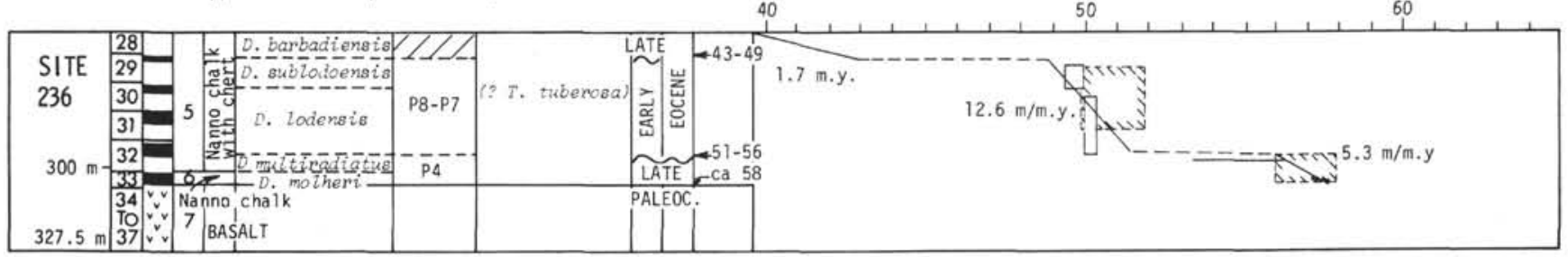

Figure 2. Summary of lithology, biostratigraphy, and sedimentation rates of Paleocene and lower Eocene sections at Sites 236 and 237. 
TABLE 2

Microfacies of Lithified Calcareous Sediments at Site 237

\begin{tabular}{|c|c|c|c|c|c|c|c|c|c|c|}
\hline ะั & 气ू & 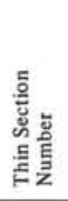 & 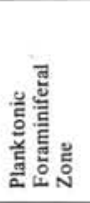 & Rock Type & $\begin{array}{l}\text { Skeletal Grains } \\
\text { (Whole or } \\
\text { Fragments) }\end{array}$ & $\begin{array}{l}\text { Identifiable Planktonic } \\
\text { Foraminifera }\end{array}$ & $\begin{array}{l}\text { Identifiable Benthonic } \\
\text { Foraminifera }\end{array}$ & 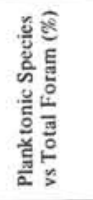 & $\begin{array}{l}\text { Infilling of } \\
\text { Fossil } \\
\text { Chambers }\end{array}$ & $\begin{array}{l}\text { Authigenic and } \\
\text { Terrigenous Grains }\end{array}$ \\
\hline 34 & 1 & 13 & P10-P9 & Sparse biomicrite & $\begin{array}{l}\text { Radiolarians }(C) \\
\text { Foraminifera (R) }\end{array}$ & $\begin{array}{l}\text { Acarinina bullbrooki } \\
\text { Morozovella aragonensis group }\end{array}$ & & $>99 \%$ & Chert & \\
\hline 37 & 2 & 15 & P7-P6 & Sparse biomicrite & $\begin{array}{l}\text { Radiolarians (C) } \\
\text { Foraminifera (R) }\end{array}$ & $\begin{array}{l}\text { Acarinina broedermanni } \\
\text { A. bullbrooki } \\
\text { Morozovella aragonensis group } \\
\text { M. quetra } \\
\text { Pseudohastigerina sp. }\end{array}$ & & $>99 \%$ & Chert & \\
\hline 38 & 1 & 13 & P7-P6 & Sparse biomicrite & $\begin{array}{l}\text { Radiolarians (C) } \\
\text { Foraminifera (R) }\end{array}$ & $\begin{array}{l}\text { Acarinina broedermanni } \\
\text { A. wilcoxensis } \\
\text { Morozovella aequa } \\
\text { M. formosa-gracilis group } \\
\text { subbotinids }\end{array}$ & & $>99 \%$ & Chert & \\
\hline 41 & 2 & 13 & PS & racked biomicrite & Foraminifera (A) & $\begin{array}{l}\text { Morozovella aequa } \\
\text { M. velascoensis }\end{array}$ & & $>99 \%$ & Chert & Glauconite (VR) \\
\hline 43 & 2 & 1 & P4 & $\begin{array}{l}\text { Packed biomicrite, } \\
\text { partially } \\
\text { recrystallized }\end{array}$ & $\begin{array}{l}\text { Foraminifera (A) } \\
\text { Radiolarians (VR) }\end{array}$ & $\begin{array}{l}\text { Morozovella aequa } \\
\text { M. laevigata } \\
\text { M. cf. velascoensis } \\
\text { Planorotalites pseudomenardii }\end{array}$ & & $>99 \%$ & Micrite & $\begin{array}{l}\text { Glauconite (VR) } \\
\text { Quartz (VR) }\end{array}$ \\
\hline 44 & 1 & 12 & P4 & Sparse biomicrite & $\begin{array}{l}\text { Radiolarians (R) } \\
\text { Foraminifera (C) } \\
\text { Sponge spicules (R) }\end{array}$ & $\begin{array}{l}\text { Chilogumbeline sp. } \\
\text { Morozovella aequa } \\
\text { M. laevigata }\end{array}$ & & $>99 \%$ & Chert & $\begin{array}{l}\text { Glauconite (C) } \\
\text { Quartz (R) } \\
\text { Feldspar (R) }\end{array}$ \\
\hline 44 & 2 & 2 & P4 & Sparse biomicrite & $\begin{array}{l}\text { Foraminifera (R) } \\
\text { Radiolarians (R) }\end{array}$ & $\begin{array}{l}\text { Morozovella aequa } \\
\text { M. velascoensis } \\
\text { subbotinids }\end{array}$ & & $>99 \%$ & Calcite & $\begin{array}{l}\text { Glauconite (C) } \\
\text { Quartz (R) }\end{array}$ \\
\hline 45 & 2 & 6 & P4-P3 & Packed biomicrite & $\begin{array}{l}\text { Foraminifera }(A) \\
\text { Sponge spicules }(R)\end{array}$ & $\begin{array}{l}\text { Chilogumbelina sp, } \\
\text { Morozovella angulata } \\
\text { M. laevigata } \\
\text { M. velascoensis } \\
\text { Planorotalites ehrenbergi group } \\
\text { Subbotina triloculinoides }\end{array}$ & Rotaliids & ca $99 \%$ & Calcite & $\begin{array}{l}\text { Glauconite (C) } \\
\text { Quartz (R) } \\
\text { Pyrite (R) }\end{array}$ \\
\hline 46 & 2 & 6 & P4-P3 & Packed biomicrite & $\begin{array}{l}\text { Foraminifera (A) } \\
\text { Radiolarians (R) } \\
\text { Echinoderms (R) }\end{array}$ & $\begin{array}{l}\text { Morozovella angulata } \\
\text { M. pusilla } \\
\text { M. velascoensis } \\
\text { Planorotalites compressa } \\
\text { P. ehrenbergi-pseudomenardii } \\
\text { group } \\
\text { Subbotina triloculinoides }\end{array}$ & & ca $99 \%$ & Calcite & $\begin{array}{l}\text { Glauconite (C) } \\
\text { Quartz (R) }\end{array}$ \\
\hline 47 & 2 & 2 & P4-P3 & Packed biomicrite & Foraminifera (A) & $\begin{array}{l}\text { Morozovella angulata } \\
\text { M. laevigata } \\
\text { M. cf. velascoensis } \\
\text { Planorotalites compressa }\end{array}$ & $\begin{array}{l}\text { Lageniids } \\
\text { Textulariids }\end{array}$ & ca $98 \%$ & Calcite & $\begin{array}{l}\text { Glauconite } \\
\text { Quartz (R) }\end{array}$ \\
\hline 48 & 1 & 4 & P4-P3 & Packed biomicrite & $\begin{array}{l}\text { Foraminifera (A) } \\
\text { Radiolarians (R) } \\
\text { Sponge spicules (R) }\end{array}$ & $\begin{array}{l}\text { Morozovella } \text { cf. acuta } \\
\text { M. angulata } \\
\text { M. laevigata } \\
\text { M. velascoensis } \\
\text { Planorotalites cf. compressa } \\
\text { Subbotina } \text { cf. triloculinoides }\end{array}$ & & $>99 \%$ & $\begin{array}{l}\text { Micrite } \\
\text { and chert }\end{array}$ & $\begin{array}{l}\text { Glauconite } \\
\text { Quartz (R) }\end{array}$ \\
\hline 48 & 2 & 120 & P4-P3 & Packed biomicrite & $\begin{array}{l}\text { Larger foraminifera } \\
\text { Bryzoans } \\
\text { Echinoderms } \\
\text { Calcareous algae }\end{array}$ & $\begin{array}{l}\text { Chilogumbelina sp. } \\
\text { Morozovella acuta } \\
\text { M. angulata } \\
\text { M. velascoensis } \\
\text { subbotinids }\end{array}$ & $\begin{array}{l}\text { Discocyclina seunesi } \\
\text { Miscellanea sp. } \\
\text { Ranikothalia bermudezi } \\
\text { Rotalia sp. }\end{array}$ & ca $30 \%$ & & \\
\hline 49 & 2 & 2 & P4-P3 & Packed biomicrite & Foraminifera (A) & $\begin{array}{l}\text { Chilogumbelina sp. } \\
\text { Morozovella angulata } \\
\text { M. cf. laevigata } \\
\text { M. cf. velascoensis } \\
\text { Planorotalites cf. compressa } \\
\text { Subbotina } \mathrm{cf} \text {. triloculinoides }\end{array}$ & Robulus sp. & $\mathrm{Ca} 98 \%$ & Micrite & Glauconite ( $\mathrm{R}$ ) \\
\hline 50 & 1 & 13 & P4-P3 & Packed biomicrite & $\begin{array}{l}\text { Foraminifera (C) } \\
\text { Radiolarians (C) } \\
\text { Sponge spicules (C) }\end{array}$ & $\begin{array}{l}\text { Chilogumbelina sp. } \\
\text { Morozovella angulata } \\
\text { M. cf. velascoensis } \\
\text { Planorotalites cf. compressa } \\
\text { Subbotina cf. triloculinoides }\end{array}$ & & $>99 \%$ & $\begin{array}{l}\text { Calcite and } \\
\text { chert }\end{array}$ & $\begin{array}{l}\text { Glauconite (R) } \\
\text { Quartz (R) }\end{array}$ \\
\hline 51 & 2 & 10 & P4-P3 & $\begin{array}{l}\text { Sparse biomicrite, } \\
\text { pellets }\end{array}$ & $\begin{array}{l}\text { Foraminifera (R) } \\
\text { Radiolarians (C) } \\
\text { Ostracodes (VR) } \\
\text { Sponge spicules (R) }\end{array}$ & $\begin{array}{l}\text { Chilogumbelina sp. } \\
\text { Morozovella cf. acuta } \\
\text { M. cf. angulata } \\
\text { M. cf. velascoensis } \\
\text { Planorotalites cf. compressa } \\
\text { Subbotina triloculinoides }\end{array}$ & Robulus sp. & $>99 \%$ & Calcite & $\begin{array}{l}\text { Glauconite (R) } \\
\text { Phosphate (VR) }\end{array}$ \\
\hline 52 & 1 & 13 & P4-P3 & Sparse biomicrite & $\begin{array}{l}\text { Foraminifera (C) } \\
\text { Radiolarians (R) } \\
\text { Echinoderms (VR) }\end{array}$ & $\begin{array}{l}\text { Morozovella } \mathrm{cf} \text {. abundocamerata } \\
\text { M. cf. angulata } \\
\text { M. cf. laevigata } \\
\text { M. cf. velascoensis } \\
\text { Planorotalites } \text { ef. compressa } \\
\text { Subbotina } \text { cf. triloculinoides }\end{array}$ & & $>99 \%$ & $\begin{array}{l}\text { Micrite and } \\
\text { calcite }\end{array}$ & Glauconite (R) \\
\hline 53 & 2 & 9 & P4-P3 & $\begin{array}{l}\text { Recrystallized } \\
\text { sparse biomicrite, } \\
\text { pellets }(\mathrm{R})\end{array}$ & $\begin{array}{l}\text { Foraminifera (C) } \\
\text { Radiolarians (R) }\end{array}$ & $\begin{array}{l}\text { Morozovella acuta } \\
\text { M. cf. angulata } \\
\text { M. cf. laevigata } \\
\text { M. velascoensis }\end{array}$ & Anomalinids & ca $98 \%$ & Calcite & Glauconite \\
\hline
\end{tabular}




\begin{tabular}{|c|c|c|c|c|c|c|c|c|c|c|}
\hline ¿ & ๕ั & $\begin{array}{l}\text { 을 } \\
\text { 以ू } \\
\text { हू ह } \\
\text { Ez }\end{array}$ & 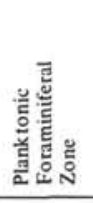 & Rock Type & $\begin{array}{l}\text { Skeletal Grains } \\
\text { (Whole or } \\
\text { Fragments }\end{array}$ & $\begin{array}{l}\text { Identifiable Planktonic } \\
\text { Foraminifera }\end{array}$ & $\begin{array}{l}\text { Identifiable Benthonic } \\
\text { Foraminifera }\end{array}$ & 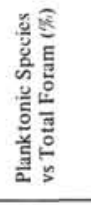 & $\begin{array}{l}\text { Infilling of } \\
\text { Fossil } \\
\text { Chambers }\end{array}$ & $\begin{array}{c}\text { Authigenic and } \\
\text { Terrigenous Grains }\end{array}$ \\
\hline 54 & 1 & 6 & P4-P3 & Packed biomicrite & Foraminifera (A) & $\begin{array}{l}\text { Morozovella angulata } \\
\text { M. cf. pusilla } \\
\text { M. cf. velascoensis } \\
\text { Planorotalites cf. ehrenbergi } \\
\text { Subbotina } \text { cf. triloculinoides }\end{array}$ & $\begin{array}{l}\text { Anomalinids } \\
\text { Bolivina sp. } \\
\text { Dentalina sp. } \\
\text { Nodosaria sp. } \\
\text { Robulus sp. }\end{array}$ & ca $98 \%$ & Micrite & $\begin{array}{l}\text { Glauconite (R) } \\
\text { Phosphate (VR) }\end{array}$ \\
\hline 56 & 1 & 5 & P3 & $\begin{array}{l}\text { Recrystallized } \\
\text { packed biomicrite, } \\
\text { pellets (R) }\end{array}$ & $\begin{array}{l}\text { Foraminifera (C) } \\
\text { Sponge spicules (R) } \\
\text { Ostracodes (VR) }\end{array}$ & $\begin{array}{l}\text { Morozovella angulata } \\
\text { Subbotina cf. triloculinoides }\end{array}$ & $\begin{array}{l}\text { Cibicides sp. } \\
\text { Dentalina sp. } \\
\text { Valvulinids }\end{array}$ & ca $95 \%$ & Calcite & Glauconite \\
\hline 58 & 1 & 6 & P3 & $\begin{array}{l}\text { Sparse biomicrite, } \\
\text { pellets (C) }\end{array}$ & $\begin{array}{l}\text { Foraminifera (C) } \\
\text { Radiolarians (C) }\end{array}$ & $\begin{array}{l}\text { Morozovella angulata } \\
\text { M. cf. pusilla }\end{array}$ & $\begin{array}{l}\text { Cibicides sp. } \\
\text { small rotaliids }\end{array}$ & ca $95 \%$ & Calcite & \\
\hline 58 & 1 & 20 & P3 & $\begin{array}{l}\text { Argillaceous } \\
\text { sparse biomicrite }\end{array}$ & $\begin{array}{l}\text { Foraminifera (C) } \\
\text { Radiolarians (R) } \\
\text { Sponge spicules (R) }\end{array}$ & $\begin{array}{l}\text { Chilogumbelina sp. } \\
\text { Morozovella angulata } \\
\text { M. pusilla }\end{array}$ & $\begin{array}{l}\text { Bolivina sp. } \\
\text { Cibicides sp. } \\
\text { Dentalina sp. }\end{array}$ & ca $95 \%$ & & Glauconite (C) \\
\hline 58 & 1 & 95 & P3 & Biosparite & $\begin{array}{l}\text { Archeolithothamnium } \\
\text { (A) } \\
\text { Foraminifera (R) } \\
\text { Ostracodes (VR) } \\
\text { Bryzoans (R) }\end{array}$ & Subbotinids & & $<30 \%$ & & \\
\hline 61 & 1 & 5 & P3 & Sparse biomicrite & $\begin{array}{l}\text { Foraminifera (R) } \\
\text { Radiolarians (R) } \\
\text { Sponge spicules (R) } \\
\text { Ostracodes (R) }\end{array}$ & $\begin{array}{l}\text { Chilogumbelina sp. } \\
\text { Morozovella angulata } \\
\text { M. cf. pusilla } \\
\text { M. cf. uncinata } \\
\text { Subbotinids }\end{array}$ & $\begin{array}{l}\text { Anomalinids } \\
\text { Urigerinids }\end{array}$ & ca $95 \%$ & Chalcedony & $\begin{array}{l}\text { Glauconite (R) } \\
\text { Quartz (R) }\end{array}$ \\
\hline 61 & 1 & 13 & P2-P1 & $\begin{array}{l}\text { Sparse biomicrite } \\
\text { partially } \\
\text { recrystallized }\end{array}$ & $\begin{array}{l}\text { Foraminifera (C) } \\
\text { Bryzoans (R) }\end{array}$ & $\begin{array}{l}\text { Morozovella } \text { cf. pusilla } \\
\text { M. uncinata } \\
\text { Planorotalites cf. ehrenbergi } \\
\text { P. trinidadensis }\end{array}$ & & ca $98 \%$ & Calcite & Quartz (R) \\
\hline 62 & 1 & 1 & P2-P1 & $\begin{array}{l}\text { Fossiliferous } \\
\text { micrite, } \\
\text { partially } \\
\text { recrystallized }\end{array}$ & $\begin{array}{l}\text { Foraminifera (R) } \\
\text { Sponge spicules (C) } \\
\text { Echinoderms (VR) }\end{array}$ & $\begin{array}{l}\text { Globogerinids } \\
\text { Morozovella uncinata }\end{array}$ & & ca $98 \%$ & Chalcedony & Glauconite (C) \\
\hline 62 & 1 & 6 & P2-P1 & Sparse biomicrite & $\begin{array}{l}\text { Foraminifera (C) } \\
\text { Sponge spicules (C) } \\
\text { Echinoderms (R) } \\
\text { Molluscs (R) }\end{array}$ & $\begin{array}{l}\text { Chilogumbelina sp. } \\
\text { Morozovella uncinata }\end{array}$ & $\begin{array}{l}\text { Cibicides sp. } \\
\text { Discorbis sp. }\end{array}$ & ca $90 \%$ & $\begin{array}{l}\text { Calcite and } \\
\text { micrite }\end{array}$ & $\begin{array}{l}\text { Glauconite (C) } \\
\text { Pyrite (C) } \\
\text { Quartz (R) } \\
\text { Phosphate (R) }\end{array}$ \\
\hline 62 & 2 & 5 & $\mathrm{P} 2-\mathrm{P} 1$ & $\begin{array}{l}\text { Sparse biomicrite } \\
\text { partially } \\
\text { recrystallized }\end{array}$ & $\begin{array}{l}\text { Foraminifera (R) } \\
\text { Bryzoans (R) } \\
\text { Echinoderms (C) } \\
\text { Molluscs (R) }\end{array}$ & $\begin{array}{l}\text { Globigerinids } \\
\text { Morozovella uncinata }\end{array}$ & $\begin{array}{l}\text { Bolivina sp. } \\
\text { Cibicides sp. } \\
\text { Discorbis sp. } \\
\text { Small rotaliids }\end{array}$ & ca $90 \%$ & Calcite & Glauconite ( $\mathrm{C}$ to $\mathrm{A})$ \\
\hline 63 & 2 & 7 & P2-P1 & $\begin{array}{l}\text { Sparse biomicrite } \\
\text { partially } \\
\text { recrystallized }\end{array}$ & $\begin{array}{l}\text { Foraminifera (R) } \\
\text { Echinoderms (C) } \\
\text { Molluscs (C) }\end{array}$ & $\begin{array}{l}\text { Planorotalites trinidadensis } \\
\text { Subbotina cf, pseudobulloides }\end{array}$ & Small rotaliids & ca $90 \%$ & $\begin{array}{l}\text { Micrite and } \\
\text { calcite }\end{array}$ & Glauconite (C to $\mathrm{A}$ ) \\
\hline 64 & 2 & 7 & P2-P1 & $\begin{array}{l}\text { Sparse biomicrite } \\
\text { partially } \\
\text { recrystallized }\end{array}$ & $\begin{array}{l}\text { Foraminifera }(C) \\
\text { Sponge spicules }(C) \\
\text { Ostracodes }(R) \\
\text { Echinoderms }(C) \\
\text { Lithothamnium, } \\
\text { small fragments (R) }\end{array}$ & $\begin{array}{l}\text { "globigerinids" } \\
\text { Morozovella uncinata } \\
\text { Planorotalites trinidadensis }\end{array}$ & Small rotaliids & ca $90 \%$ & Calcite & $\begin{array}{l}\text { Glauconite (C) } \\
\text { Quartz (R) }\end{array}$ \\
\hline 65 & 1 & 8 & P2-P1 & $\begin{array}{l}\text { Sparse biomicrite } \\
\text { largely } \\
\text { recrystallized }\end{array}$ & $\begin{array}{l}\text { Foraminifera (R) } \\
\text { Sponge spicules }(C) \\
\text { Molluscs }(R) \\
\text { Echinoderms (R) }\end{array}$ & $\begin{array}{l}\text { Chilogumbelina sp. } \\
\text { Morozovella uncinata } \\
\text { Subbotina cf. pseudobulloides }\end{array}$ & $\begin{array}{l}\text { Small rotaliids } \\
\text { Robulus sp. }\end{array}$ & ca $90 \%$ & & $\begin{array}{l}\text { Glauconite (C) } \\
\text { Pyrite (C) }\end{array}$ \\
\hline 65 & 2 & 1 & P2-P1 & $\begin{array}{l}\text { Sparse biomicrite } \\
\text { partially } \\
\text { recrystallized }\end{array}$ & $\begin{array}{l}\text { Foraminifera (R) } \\
\text { Sponge spicules }(A) \\
\text { Echinoderms (R) }\end{array}$ & $\begin{array}{l}\text { Small globogerinid } \\
\text { Morozovella uncinata }\end{array}$ & $\begin{array}{l}\text { Anomalinids } \\
\text { Small rotaliids }\end{array}$ & ca $90 \%$ & Chalcedony & Glauconite (R) \\
\hline 65 & 2 & 12 & P2-P1 & $\begin{array}{l}\text { Sparse biomicrite } \\
\text { partially } \\
\text { recrystallized }\end{array}$ & $\begin{array}{l}\text { Foraminifera (R) } \\
\text { Echinoderms (C) }\end{array}$ & $\begin{array}{l}\text { Morozovella uncinata } \\
\text { Planorotalites trinidadensis }\end{array}$ & Small rotaliids & ca $90 \%$ & Micrite & $\begin{array}{l}\text { Glauconite (R) } \\
\text { Pyrite (C) }\end{array}$ \\
\hline 65 & 3 & 5 & P2-P1 & $\begin{array}{l}\text { Sparse biomicrite } \\
\text { partially } \\
\text { recrystallized }\end{array}$ & $\begin{array}{l}\text { Foraminifera }(R) \\
\text { Sponge spicules }(R) \\
\text { Echinoderms (R) }\end{array}$ & Morozovella uncinata & $\begin{array}{l}\text { Small rotaliids } \\
\text { Dentalina sp. }\end{array}$ & ca $90 \%$ & Calcite & Glauconite (R) \\
\hline 66 & 1 & 11 & P2-P1 & $\begin{array}{l}\text { Fossiliferous } \\
\text { micrite }\end{array}$ & $\begin{array}{l}\text { Foraminifera (R) } \\
\text { Sponge spicules (R) } \\
\text { Ostracodes (VR) } \\
\text { Echinoderms, small } \\
\text { Fragments (R) }\end{array}$ & $\begin{array}{l}\text { Chilogumbelina sp. } \\
\text { Planorotalites trinidadensis } \\
\text { Subbotina cf. triloculinoides }\end{array}$ & & $(90 \%)$ & Chalcedony & $\begin{array}{l}\text { Glauconite (R) } \\
\text { Quartz (R) }\end{array}$ \\
\hline 66 & 2 & 14 & P2-P1 & $\begin{array}{l}\text { Fossiliferous } \\
\text { micrite, partially } \\
\text { recrystallized }\end{array}$ & $\begin{array}{l}\text { Foraminifera (R) } \\
\text { Sponge spicules (R) } \\
\text { Ostracodes (R) } \\
\text { Molluscs (R) }\end{array}$ & Small "globigerinids" & & $(95 \%)$ & $\begin{array}{l}\text { Chert and } \\
\text { calcite }\end{array}$ & + \\
\hline 66 & 3 & 17 & P2-P1 & $\begin{array}{l}\text { Fossiliferous } \\
\text { micrite }\end{array}$ & $\begin{array}{l}\text { Foraminifera }(R) \\
\text { Sponge spicules }(C) \\
\text { Echinoderms }(R) \\
\text { Molluses (R) }\end{array}$ & Planorotalites trinidadensis & & $(95 \%)$ & Chert & \\
\hline
\end{tabular}




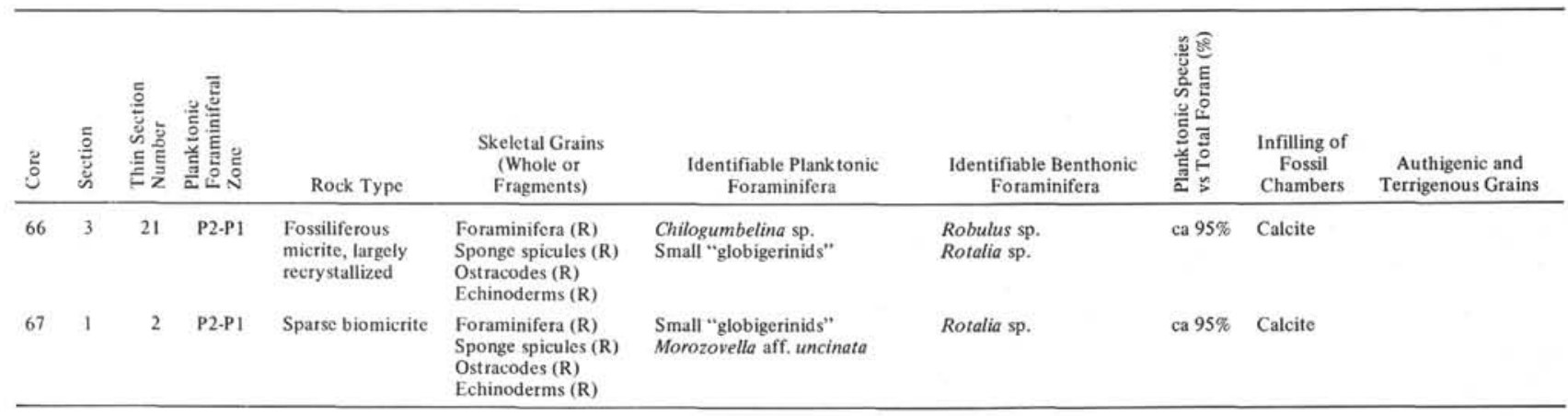

Note: $(A)=$ abundant; $(C)=$ common; $(R)=$ rare; $(V R)=$ very rare; $(95 \%)=$ foraminifera too rare for a valid estimate of $\%$.

species comprise less than $50 \%$ of the foraminiferal fauna on the continental shelf; their frequency increases to about $50 \%$ at the shelf edge and to very high values $(>99 \%)$ at bathyal depths. However, in an open-ocean environment near banks or shoals, or in areas near narrow shelves, a high planktonic/benthonic ratio may occur closer to shore. Another important faunal relationship providing evidence as to depth of deposition is that of the relative frequency of planktonic foraminifera and radiolarians. Today, radiolarian ooze is found primarily at great depths. With increasing depths, at depths approaching the lysocline (the depth at which the preservation of foraminiferal assemblages deteriorates rapidly), the relative frequency of calcareous foraminifera decreases while siliceous radiolarians increase in abundance and eventually become dominant below the CCD. Morphological trends in various benthonic species also appear to be correlated with water depth. For example, some species of the bathyal zone show a striking increase in size with increasing water depths (Bandy, 1963; Theyer, 1971).

Many modern foraminiferal species show the same upper depth limit in widely distributed geographic areas. Some of these depth indicators have isomorphs that occur in the Paleogene (Bandy, 1960; 1970). Bandy and Chierici (1966) have shown that the upper depth limits of isobathyal species are similar in various water masses of the world's oceans and suggested that variations of water depth in the bathyal realm have probably not served to alter the upper depth of this group of species. Douglas (1973b), however, has provided evidence to suggest that an interpretative error may result from estimates of paleodepth of fossil assemblages derived by analogy with modern benthonic assemblages, because of the migrational displacement of benthonic species throughout the Tertiary in response to fluctuations in the temperature and circulation of bottom water. Caution is especially needed for interpretation of populations older than middle Miocene, the time when modern deep-sea benthonic assemblages began to emerge.

Although the number of Paleocene and Eocene paleobathymetric studies of benthonic foraminifera is limited, especially with respect to bathyal and abyssal populations, these studies are of great value for comparison between geographic regions. A cosmopolitan distribution of benthonic assemblages is expected during early Tertiary time because of the more uniform thermal structure of the oceans and the more equitable climatic conditions.
Bandy (1970) considered the association of a "Pleurostomella-Nuttalides fauna" with a rich radiolarian assemblage to be indicative of "abyssal" water depths $(>2000 \mathrm{~m})$ during the late Paleocene and early Eocene of the Central America area. In this study we assign a paleodepth of 2000 to 2500 meters to a similar fauna, characterized by Nuttallides truempyi; and robust pleurostomellids. Tjalsma (personal communication) investigated Paleocene faunas from the western Atlantic (Gulf of Mexico and Carribbean) and South Atlantic (Rio Grande Rise) from DSDP sites and recognized deep-water $(>1000$ m) assemblages ("Velasco-type fauna") characterized by, among other species, robust anomalinids (Gavelinella danica, G. velascoensis), Nuttalides truempyi, and various gyroidinids and buliminids. He has examined material from our study, which he compared to his material, and found deep-water species common to both Atlantic and Indian ocean assemblages.

The bathymetric distribution of Paleocene benthonic assemblages from the Tethyan and circum-Atlantic regions was studied by Berggren (in press, a, b) and Berggren and Phillips (1971) who assigned upper neritic to upper bathyal water depths to a "Midway-type fauna. 'For example, faunas including larger foraminifera such as those of a few Paleocene horizons at Site 237 were interpreted as upper neritic assemblages; whereas faunas composed, as in most of the Paleocene section at Site 237, of buliminids, Cibicides Gaudryina, Gavelinella, Osangularia, Oridorsalis, and Vaginulina were interpreted as representative of lower neritic to upper bathyal water depths. Douglas (1973a) considered assemblages composed of Aragonia, Gaudryina, Osangularia, and Spiroplectammina to be indicative of "deep-sea assemblages" for the Paleocene in the northwest Pacific Ocean. Gibson (1973) arrived at a similar paleobathymetric interpretation (approximately $600 \mathrm{~m}$ ) for "Midway-type assemblages" of the California coastal area. Early Eocene assemblages in the California basins appear to be shoaler than that at Sites 236 and 237. Nuttalides truempyi was not found in the Californian faunas and furthermore, the amphimorphinids, lagenids, and plectofrondiculariids characteristic of the California sequences are lacking or poorly developed at the Indian Ocean sites.

\section{Attribution of Depth Assemblages}

Four depth assemblages were recognized in the Paleocene and early Eocene faunas at Sites 236 and 237. The 


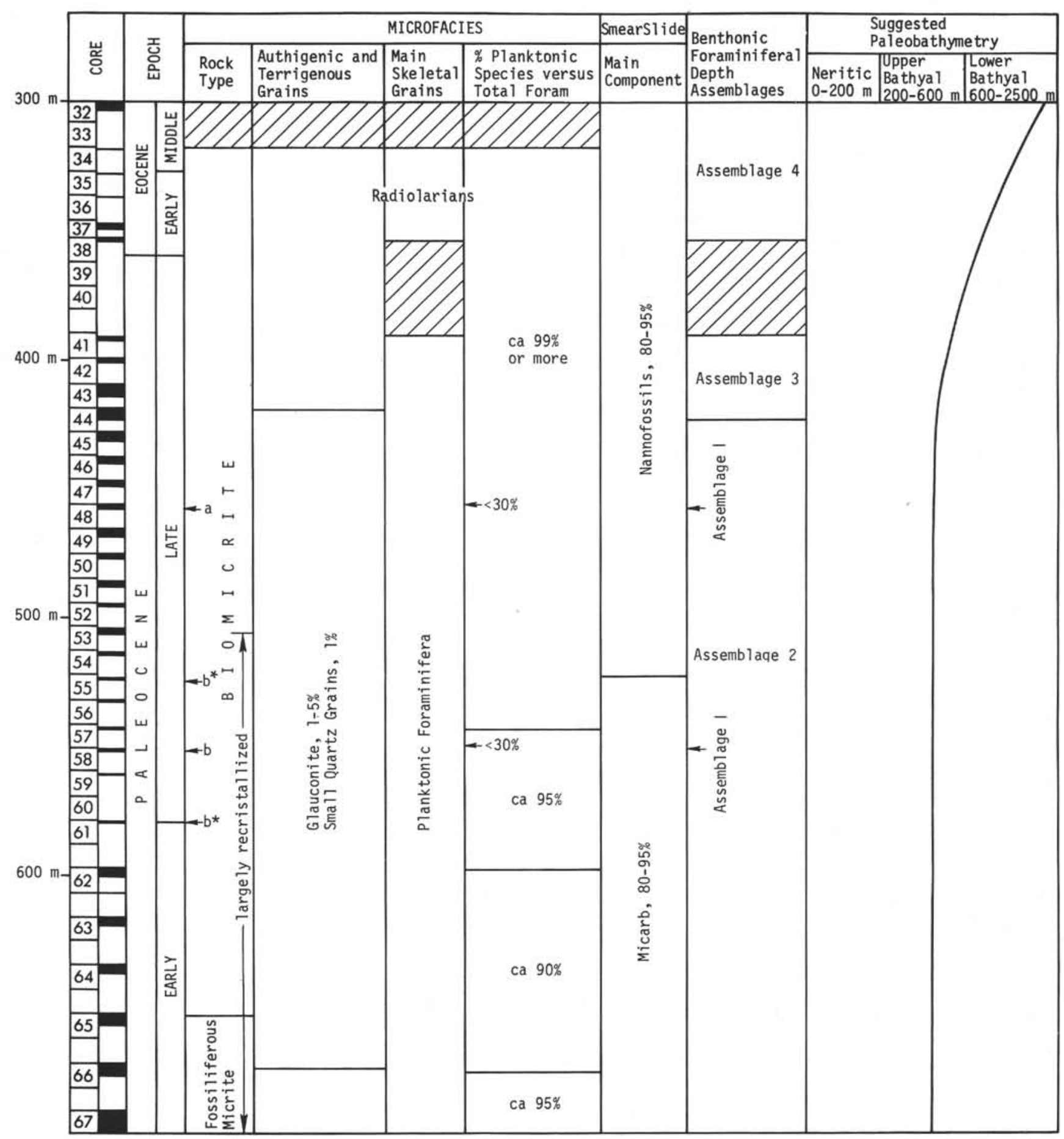

a: Larger foraminifera limestone (packed biomicrite)

b: Calcareous algal limestone (biosparite); $b^{\star}$ : no thin section available

Figure 3. Summary of variations of microtextural components, benthonic foraminiferal assemblages, and bathymetry of Paleocene and lower Eocene sediments of Site 237. 
distribution of these assemblages at the sites is indicated on Tables 3 and 4 and Figure 3.

Assemblage 1 (Paleocene): Upper neritic $(<50 \mathrm{~m})$. Characterized by larger foraminifera (Discocyclina, Ranikhotalia) various rotaliids, and the calcareous algae Archaeolithothamnium.

Assemblage 2 (Paleocene): Lower neritic to upper bathyal (50-600 m). "Midway-type fauna" characterized by Anomalina midwayensis, Cibicides alleni, Gavelinella danica, Gyroidina girardana, G. globosa, G. nitida, Loxostomum applinae, Marssonella oxycona, Pleurostomella paleocenica, Pullenia coryelli, Stilostomella spp., and Vaginulina longiforma among numerous others.

Assemblage 3 (Paleocene): Lower bathyal (600-2500 m). Dominated by Nuttalides truempyi in co-occurrence with Pseudovalvulineria beccariformis and Gavelinella aff. G. danica among others.

Assemblage 4 (Eocene): Lower bathyal (600-2500 m). Dominated by Nuttalides truempyi. Anomalina dorri aragonensis replaces the Paleocene morphotypes ( $P$. beccariformis and $G$. aff. $G$. danica). Forms such as Gyroidina planata and Stilostomella kressenbergensis also appear.

The change in morphology of forms assignable to Pleurostomella paleocenica to those referred as Pleurostomella aff. $P$. paleocenica suggests a trend of increasing size and robustness with increasing water depth, because this morphological trend parallels the increase in abundance of the deep-water species Nuttalides truempyi.

\section{DISCUSSION}

The Paleocene and early Eocene benthonic assemblages (assemblages 3 and 4) at Site 236 are characteristic of deep water, as shown by the dominance throughout the section of Nuttalides truempyi and the presence of robust pleurostomellids. Reconstruction of former water depths at the site derived from the age/depth constancy of basaltic oceanic basement (Sclater et al., 1971) shows that the paleodepth at Site 236 was approximately 2000 meters for the upper Paleocene sediments just above basement, deepening to approximately 2500 meters for lower Eocene sediments approximately $50 \mathrm{~m} . \mathrm{y}$. old (Figure 4). A deepwater environment interpreted from the foraminiferal assemblages is therefore in good agreement with these lower bathyal paleodepths.

The benthonic fauna in the lower part of the section at Site 237 between Cores 67 and 49 is poorly preserved and nondiverse, and consists of very few individuals. However the presence of such elements as Anomalina midwayensis, $A$. welleri, Pleurostomella paleocenica, Pullenia quinqueloba angusta, Stilostomella paleocenica, and Vaginulina longiforma suggests a lower neritic to upper bathyal environment. In the interval between Cores 49 and 44 the preservation is good and the fauna is substantially more common and diverse. It contains such typical Midway faunal elements as: Anomalina midwayensis, A. welleri, Bulimina arkadelphiana midwayensis, Clavulina aspera whitei, C. midwayensis, Eponides aff. E. bollii, frondiculariids, Gavelinella danica, Gyroidina globosa, G. nitida, Palmula reticulata, Pleurostomella paleocenica, Pseudovalvulineria beccariformis, Pullenia coryelli, Stilostomella paleocenica, Trifarina herberti, Vaginulina longiforma. This assemblage (assemblage 2) represents lower neritic to upper bathyal depths, and includes no lower bathyal or abyssal indicators. The deep-water species Nuttallides truempyi which characterizes assemblage 3, first appears in Sample $44,2,116-118 \mathrm{~cm}$; it occurs rarely in the first samples above this level and increases in abundance upwards until it dominates the Eocene faunas. A transition zone from the shallower assemblage 2 to the deeper assemblage 3 occurs in the interval between Cores 44 and 42, where the two assemblages overlap. The early Eocene assemblage (assemblage 4) is very similar to the early Eocene assemblage at Site 236 , differences in preservation account for the minor discrepancies.

It thus appears that during late Paleocene (later than 57-58 m.y.) and early Eocene time a lower bathyal (600-2500 m) environment prevailed at both Sites 236 and 237. The sediments contain deep-water benthonic assemblages (assemblages 3 and 4). The foraminiferal fauna shows a very high planktonic/benthonic ratio, with planktonic species comprising more than $99 \%$ of the fauna. Depth of deposition at Site 236 was on the order of 2000 to 2500 meters and may have been of the same order of magnitude at Site 237. However, as the upper depth limit of Paleogene benthonic species is not well known, the assemblages at Site 237 may reflect a shallower depth as well. It is probable that the depth at Site 237 during late P.4 and Discoaster molheri Zone time (Core 42) was shallower than the contemporaneous depth at Site 236, as shown by the greater abundance of Nuttallides truempyi at the latter site. Site 237, however, may have reached a depth as great as that at Site 236 in Eocene time, when $N$. truempyi become dominant. The presence of the deep-water ostracode Abyssocythere in middle Eocene sediments of Site 237 (Benson, this volume) support this bathymetric attribution. Populations of Abyssocythere are well developed in Eocene deep-water sediments of Atlantic DSDP sites. The depth range of modern representatives of this form is from 2000 to 4500 meters, with a peak in abundance at 3000 meters (Richard H. Benson, personal communication). An increase in the radiolarian/planktonic foraminifera ratio in middle and late Eocene sediments of both Site 236 and 237 may indicate that during that time, a time of shallowing of the CCD (Berger, 1972), the depth at these sites was close to the lysocline level.

The average accumulation rate for upper Paleocene sediments younger than $57-58 \mathrm{~m} . \mathrm{y}$. is approximately 11 $\mathrm{m} / \mathrm{m} . \mathrm{y}$. at Site 237 and $5 \mathrm{~m} / \mathrm{m} . \mathrm{y}$. at Site 236. Sedimentation slowed significantly near the end of the Paleocene. A period of nondeposition of about 5 m.y. spanned the Paleocene/Eocene boundary at Site 236, whereas at Site 237 sediments accumulated at a reduced rate of $7.5 \mathrm{~m} / \mathrm{m} . \mathrm{y}$. In late early Eocene time, sedimentation resumed at Site 236 with a rate of about $13 \mathrm{~m} / \mathrm{m}$.y., and at Site 237 the accumulation rate increased again at the beginning of the middle Eocene to a value of approximately $17 \mathrm{~m} / \mathrm{m} . \mathrm{y}$. (Figure 2). The average sedimentation rate for sediments laid down at Site 237 between about 57 and 49 m.y.B.P. (latest Paleocene and early Eocene) is approximately 13 $\mathrm{m} / \mathrm{m} . \mathrm{y}$.

Assemblage 3, of late Paleocene age, lies directly upon basalt at Site 236, while at Site 237 it overlies 280 meters 
TABLE 3

Distribution of Benthonic Foraminifera in Paleocene and Lower Eocene Sediments at Site 236

\begin{tabular}{|c|c|c|c|c|c|c|c|c|c|c|c|c|}
\hline \multirow{3}{*}{ Planktonic Foraminiferal Zone } & \multicolumn{4}{|c|}{ Eocene } & \multicolumn{8}{|c|}{ Paleocene } \\
\hline & \multicolumn{4}{|c|}{ Early } & \multicolumn{8}{|c|}{ Late } \\
\hline & \multicolumn{4}{|c|}{ P8-P7 } & \multicolumn{8}{|c|}{ P4 } \\
\hline \multirow[b]{2}{*}{ Taxa } & \multicolumn{4}{|c|}{ Assemblage 4} & \multicolumn{8}{|c|}{ Assemblage 3} \\
\hline & 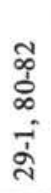 & 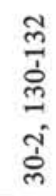 & 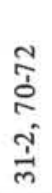 & 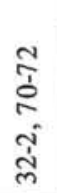 & 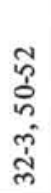 & $\begin{array}{l}\text { U } \\
\text { లే }\end{array}$ & $\begin{array}{l}\frac{g}{1} \\
\frac{1}{0} \\
\dot{0} \\
\text { ले }\end{array}$ & $\begin{array}{l}\stackrel{\infty}{\infty} \\
\stackrel{\infty}{=} \\
\dot{m}\end{array}$ & $\begin{array}{l}\text { ๙े } \\
\text { ठू } \\
\text { ஸें }\end{array}$ & $\begin{array}{l}\text { సે } \\
\text { ટે } \\
\text { กิ } \\
\text { ले }\end{array}$ & $\begin{array}{l}\text { ले } \\
\text { mे } \\
\text { mे } \\
\text { ले }\end{array}$ & $\frac{5}{\grave{\delta}}$ \\
\hline Ammopalmula sp. & & $\mathrm{X}$ & & & & & & & & & & \\
\hline Anomalina dorri aragonensis Nuttall & & $\mathrm{X}$ & $\mathrm{X}$ & & & & & & & & & \\
\hline Anomalina midwayensis (Plummer) & & & & & & & $\mathrm{X}$ & & & & & \\
\hline Anomalina praespissiformis Cushman and Bermudez & & $\mathrm{X}$ & & & & & & & & & & \\
\hline Anomalina welleri (Plummer) & & & & & & $\mathrm{X}$ & $\mathrm{X}$ & & & & & $\mathrm{X}$ \\
\hline Anomalina sp. & & & $\mathrm{X}$ & & & & & & & & & \\
\hline Aragonina aragonensis (Nuttall) & $\mathrm{X}$ & & $\mathrm{x}$ & & & & & & & & & \\
\hline Aragonina velascoensis (Cushman) & & & & & & & & $\mathrm{X}$ & & & & $\mathrm{X}$ \\
\hline Astacolus sp. & & & & & & $\mathrm{X}$ & $\mathrm{X}$ & $\mathrm{X}$ & & & & \\
\hline \multicolumn{13}{|l|}{ Asterigerina crassaformis (Cushman and Siegfus)? } \\
\hline Bathysiphon eocenicus Cushman and Hanna? & & & & & $\mathrm{X}$ & & & & & & & \\
\hline \multicolumn{13}{|l|}{ Bolivina cf. B. anglica Cushman } \\
\hline Bolivinoides delicatula Cushman & & & & & & & & & & & & $\mathrm{X}$ \\
\hline Bulimina beaumonti Cushman and Renz & & & & & & & & & & $\mathrm{X}$ & & \\
\hline Bulimina cf. B. bradburyi Martin & & $\mathrm{X}$ & & & & & & & $\mathrm{X}$ & & & \\
\hline Bulimina cf. B. eccentrica & & $\mathrm{X}$ & & & & & & & & & & \\
\hline Bulimina excavata Cushman and Parker & & & & & & $\mathrm{X}$ & & & $\mathrm{X}$ & $\mathrm{X}$ & & \\
\hline Bulimina impendens Parker and Bermudez & & & & & & $\mathrm{X}$ & & & & & & \\
\hline Bulimina microcostata Cushman and Parker & & $\mathrm{X}$ & & & & & $\mathrm{X}$ & & & & & \\
\hline \multicolumn{13}{|l|}{ Bulimina cf. B. microcostata Cushman and Parker } \\
\hline Bulimina semicostata & $\mathrm{X}$ & $\mathrm{X}$ & $\mathrm{X}$ & & & & & & & & & \\
\hline Bulimina aff. $B$. versa & & $\mathrm{X}$ & $\mathrm{X}$ & & & & & & & & & \\
\hline Bulimina spp. & & & & & & $\mathrm{X}$ & & & $\mathrm{X}$ & & $\mathrm{X}$ & \\
\hline Cibicides spiropunctatus Galloway and Morrey & & $\mathrm{X}$ & $\mathrm{X}$ & & & $\mathrm{X}$ & $\mathrm{X}$ & $\mathrm{X}$ & & $\mathrm{X}$ & & \\
\hline Cibicides cf. C. spiropunctatus Galloway and Morrey & $\mathrm{X}$ & & & & & & & & & & & $\mathrm{X}$ \\
\hline Cibicides spp. & $\mathrm{X}$ & & & & & & & & & & & \\
\hline Clavulina cf. C. aspera whitei Cushman and Jarvis & & & & & & & $\mathrm{X}$ & & & 4 & & $\mathrm{X}$ \\
\hline Clavulina cf. C. petrosa (Cushman and Bermudez) & & & & & & & $\mathrm{X}$ & & & & & \\
\hline Clavulina cf. C. tricarinata (Reuss) & & & & & & & & & & & $\mathrm{X}$ & \\
\hline Clavulina spp. & & & & & & $\mathrm{X}$ & & & & & & \\
\hline Dentalina colei Cushman and Dusenbury & $\mathrm{X}$ & & & & & & $\mathrm{X}$ & & $\mathrm{X}$ & & & \\
\hline \multicolumn{13}{|l|}{ Dentalina dusenburyi Beck } \\
\hline Dentalina cf. D. eocenica Cushman & & & & & & & & & $\mathrm{X}$ & & & \\
\hline \multicolumn{13}{|l|}{ Dentalina cf. D. pseudo-obliquistriata (Plummer) } \\
\hline \multicolumn{13}{|l|}{ Dentalina soluta Reuss } \\
\hline Dentalina spp. & $\mathrm{X}$ & & $\mathrm{X}$ & & & $\mathrm{X}$ & & $\mathrm{X}$ & & $\mathrm{X}$ & & $\mathrm{X}$ \\
\hline \multicolumn{13}{|l|}{ Eponides aff. E. bolli Cushman and Renz } \\
\hline Eponides spp. & & $\mathrm{X}$ & $\mathrm{X}$ & & & & & $\mathrm{X}$ & $\mathrm{X}$ & & & \\
\hline Fissurina orbignyana Seguenza & & & & & & & & & & & & $\mathrm{X}$ \\
\hline Gaudryina laevigata Franke & $\mathrm{X}$ & $\mathrm{X}$ & & & & & $\mathrm{X}$ & $\mathrm{X}$ & & & & $\mathrm{X}$ \\
\hline Gaudryina aff. G. laevigata Franke & & & & & & & & & & $\mathrm{X}$ & & \\
\hline Gavelinella aff. $G$. danica (Brotzen) & & & & & & & & $\mathrm{X}$ & & & & $\mathrm{X}$ \\
\hline
\end{tabular}


TABLE 3 - Contimued

\begin{tabular}{|c|c|c|c|c|c|c|c|c|c|c|c|c|}
\hline \multirow{2}{*}{ Epoch } & \multicolumn{4}{|c|}{ Eocene } & \multicolumn{8}{|c|}{ Paleocene } \\
\hline & \multicolumn{4}{|c|}{ Early } & \multicolumn{8}{|c|}{ Late } \\
\hline Planktonic Foraminiferal Zone & \multicolumn{4}{|c|}{ P8-P7 } & \multicolumn{8}{|c|}{ P4 } \\
\hline Depth Assemblage & \multicolumn{4}{|c|}{ Assemblage 4} & \multicolumn{8}{|c|}{ Assemblage 3} \\
\hline $\begin{array}{r}\text { Sample } \\
\text { (Interval } \\
\text { in } \mathrm{cm} \text { ) }\end{array}$ & $\begin{array}{l}\infty \\
0 \\
\infty \\
\hat{1} \\
\hat{1}\end{array}$ & 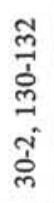 & 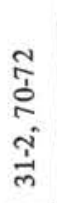 & 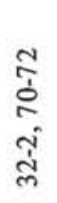 & 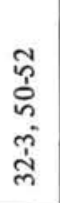 & $\begin{array}{l}\text { ర్ } \\
\text { है }\end{array}$ & 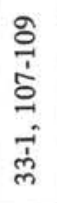 & $\begin{array}{l}\frac{0}{1} \\
\stackrel{\infty}{\Xi} \\
\frac{1}{n} \\
\tilde{n}\end{array}$ & $\begin{array}{l}\text { స̃ } \\
\text { ठे } \\
\text { लें } \\
\text { ले }\end{array}$ & 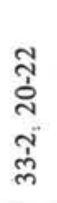 & $\begin{array}{l}\text { ले } \\
\stackrel{m}{m} \\
\text { m. } \\
\tilde{m}\end{array}$ & 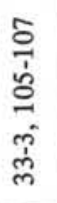 \\
\hline Gavelinella hyphalus (Fisher) & & & & & & $\mathrm{X}$ & $\mathrm{X}$ & & & & & \\
\hline Globolina sp. & & & & & & & & & & & & $\mathrm{X}$ \\
\hline Gyroidina girardana (Reuss) & $\mathrm{X}$ & & & & & & & $\mathrm{X}$ & & & & \\
\hline Gyroidina globosa (Hagerow) & & & & & & $\mathrm{X}$ & $\mathrm{X}$ & $\mathrm{X}$ & $\mathrm{X}$ & & & $\mathrm{X}$ \\
\hline Gyroidina nitida (Reuss) & & & & & & & & & & $\mathrm{X}$ & & \\
\hline Gyroidina planata Cushman & & & $\mathrm{X}$ & & & & & & & & & \\
\hline Lagena acuticosta Reuss & & & & & & $\mathrm{X}$ & & & & & & \\
\hline Lagena cf. L. laevis (Montagu) & & & & & & & $\mathrm{X}$ & & & & & $\mathrm{X}$ \\
\hline Lagena spp. & $\mathrm{X}$ & & & & & $\mathrm{X}$ & $\mathrm{X}$ & & & & & \\
\hline Lenticulina cf. L. rosetta (Gimbel) & & & & & & & & & & & & $\mathrm{X}$ \\
\hline Lenticulina velascoensis White & & & & & & $\mathrm{X}$ & $\mathrm{X}$ & $\mathrm{X}$ & & $\mathrm{X}$ & & $\mathrm{X}$ \\
\hline Lenticulina aff. $L$. vortex (Fichtel and Moll) & & & & & & & & & & & & $\mathrm{X}$ \\
\hline Loxostomum trinitatensis Cushman and Renz & & & & & & $\mathrm{X}$ & $\mathrm{X}$ & & & & & \\
\hline Marginulina cf. M. subrecta Franke & & & & & & $\mathrm{X}$ & & & & & & \\
\hline \multicolumn{13}{|l|}{ Marginulina spp. } \\
\hline Marssonella oxycona (Reuss) & & & & & & $\mathrm{X}$ & $\mathrm{X}$ & $\mathrm{X}$ & $\mathrm{X}$ & $\mathrm{X}$ & & $\mathrm{X}$ \\
\hline Marssonella cf. M. oxycona (Reuss) & $\mathrm{X}$ & & & & & & & & & & & \\
\hline Melonis aff. M. planatus (Cushman and Thomas) & $\mathrm{X}$ & & & & & $\mathrm{X}$ & $\mathrm{X}$ & & & $\mathrm{X}$ & & $\mathrm{X}$ \\
\hline Neoeponides hildebrandti Fisher & & & & & & & & & & & & $\mathrm{X}$ \\
\hline Nodosarella advena Cushman and Siegfus & & $\mathrm{X}$ & $\mathrm{X}$ & & & & & & & & & \\
\hline Nodosarella aff. $N$. attenuata (Plummer) & $\mathrm{X}$ & & & & & & & & & & & \\
\hline Nodosarella spp. & & $\mathrm{X}$ & & & & & $\mathrm{X}$ & & & & & \\
\hline Nodosaria latejugata Gümbel & & & $\mathrm{X}$ & & & & & & $\mathrm{X}$ & & & \\
\hline Nodosaria sp. & & & & & & & $\mathrm{X}$ & $\mathrm{X}$ & & & & \\
\hline Nuttallides truempyi (Nuttall) & $\mathrm{X}$ & $\mathrm{X}$ & $\mathrm{X}$ & $\mathrm{X}$ & & $\mathrm{X}$ & $\mathrm{X}$ & $\mathrm{X}$ & $\mathrm{X}$ & $\mathrm{X}$ & & $\mathrm{X}$ \\
\hline Oridorsalis umbonatus Reuss? & $\mathrm{X}$ & & $\mathrm{X}$ & & & & & & & & & $\mathrm{X}$ \\
\hline Osangularia culter (Parker and Jones) & $\mathrm{X}$ & $\mathrm{X}$ & $\mathrm{X}$ & & & & & & & & & \\
\hline Osangularia aff. O. culter (Parker and Jones) & & & & $\mathrm{X}$ & & & & & & & & \\
\hline Palmula aff. P. delicatissima (Plummer) & & & & & & & $\mathrm{X}$ & & & & & \\
\hline Pleurostomella aff. $P$. paleocenica Cushman & $\mathrm{X}$ & $\mathrm{X}$ & & & & $\mathrm{X}$ & $\mathrm{X}$ & & $\mathrm{X}$ & $\mathrm{X}$ & & $\mathrm{X}$ \\
\hline Pseudogloborotalia florealis (White) & & & & & & $\mathrm{X}$ & $\mathrm{X}$ & & & & & $\mathrm{X}$ \\
\hline Pseudonodosaria manifesta (Reuss) & & & & & & & $\mathrm{X}$ & & $\mathrm{X}$ & & & \\
\hline Pseudonodosaria spp. & & & $\mathrm{X}$ & & & & $\mathrm{X}$ & & & & & $\mathrm{X}$ \\
\hline Pseudovalvulineria beccariformis (White) & & & & & & $\mathrm{X}$ & & $\mathrm{X}$ & $\mathrm{X}$ & $\mathrm{X}$ & & \\
\hline Pullenia coryelli White & & & & & & $\mathrm{X}$ & $\mathrm{X}$ & $\mathrm{X}$ & $\mathrm{X}$ & $\mathrm{X}$ & & \\
\hline Pullenia quinqueloba angusta Cushman and Todd & $\mathrm{X}$ & & & & & & & & & & & \\
\hline Pullenia sp. & $\mathrm{X}$ & & & & & & & & & & & \\
\hline Spiroplectammina excolata (Cushman) & & & & & & & $\mathrm{X}$ & $\mathrm{X}$ & & & & $\mathrm{X}$ \\
\hline Spiroplectammina mexiaensis Lalicker & & & & & & & $\mathrm{X}$ & & & & & \\
\hline Spiroplectammina cf. S. spectabilis (Grzybowskii) & & & & & & & & & & & & $\mathrm{X}$ \\
\hline Spiroplectammina sp. & & & & & & & & & $\mathrm{X}$ & $\mathrm{X}$ & & \\
\hline Stilostomella cf. $S$. bradyi (Cushman) & $\mathrm{X}$ & & & & & & & & & & & \\
\hline
\end{tabular}


TABLE 3 - Continued

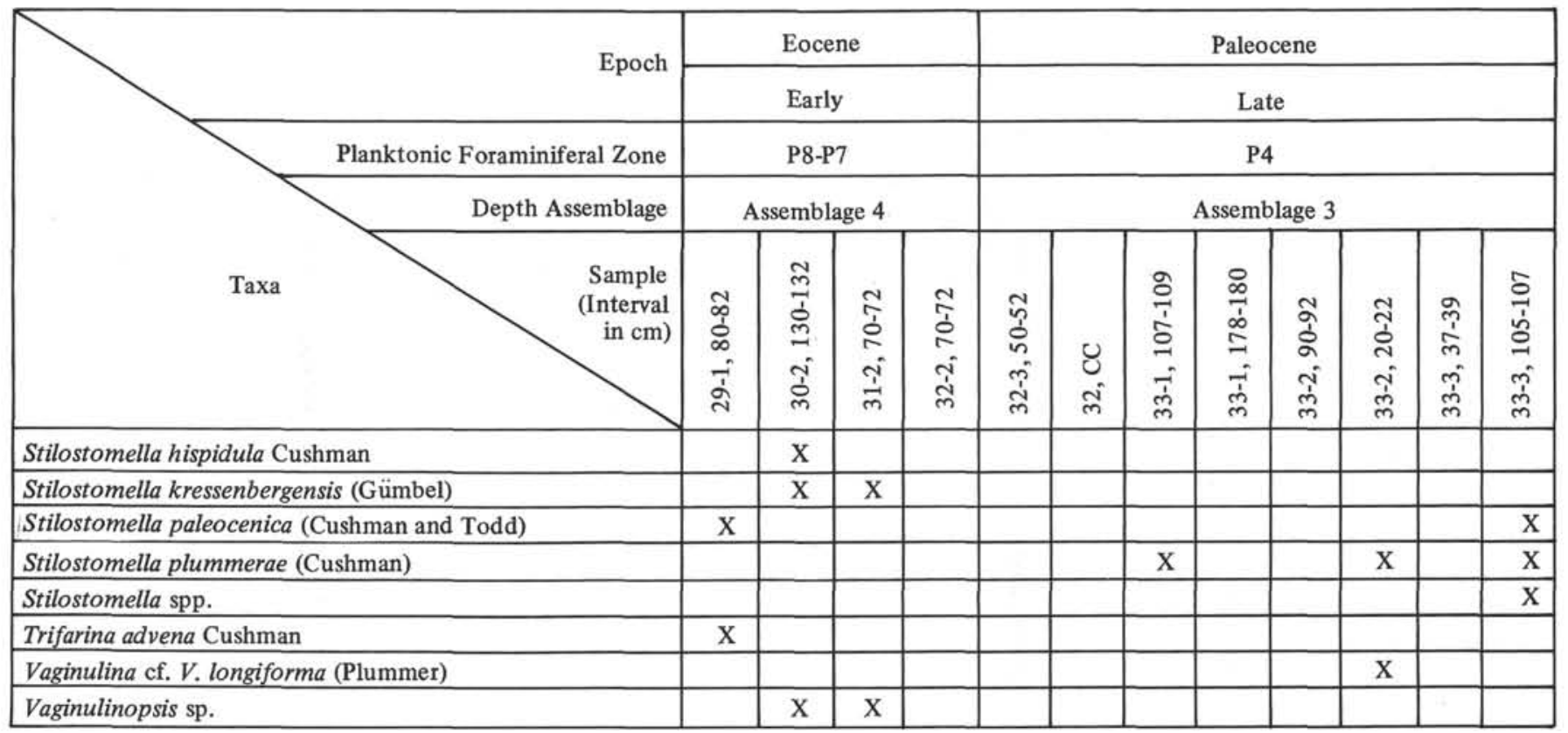

of older sediments. At the latter site the hole was terminated in sediments approximately 62 m.y. old (P.1 and Cruciplacolithus tenuis zones) and basement was not reached. The lower 280 meters of section at Site 237 shows a sedimentary history different from that of the overlying sequence. Sediments include a characteristic Midway benthonic assemblage (assemblage 2), which reflects lower neritic to upper bathyal water depths with admixtures in several thin horizons of displaced upper neritic fauna (assemblage 1). The environment, however is clearly pelagic, well below shelf depth as planktonic foraminifera constitute $95 \%$ or more of the foraminiferal population throughout the section, except in the few horizons with displaced neritic material in which their frequency is much lower $(<30 \%)$. An upper bathyal environment of several hundred meters (600 $\mathrm{m}$ or less) thus appears to have persisted from approximately 62 to $57-58$ m.y.B.P. This water depth is in the range at which glauconite is most commonly formed (Porrenga, 1967). The presence of glauconite (1\% to $5 \%$ ) in the rocks throughout this part of the section, as pellets and in some instances as fillings of foraminiferal tests, would thus support the water depth inferred from benthonic assemblages. The presence of fine quartz grains (1\%) throughout this part of the sequence is also consistent with this bathymetric interpretation. It is possible, however, that these components were transported downslope and cannot be used as bathymetric indicators.

The very high sedimentation rate which average 68.2 $\mathrm{m} / \mathrm{m}$.y. for the lower 290 meters of sediments (a rate of accumulation about five times higher than for the succeeding upper Paleocene and lower Eocene sequence) and the admixture of slumped shallow-water sediments indicate that the location of Site 237 functioned as a sediment trap during the early Paleocene and early late Paleocene. In addition to slumping of coarse material from nearby banks or shoals on a few occasions, it is probable that a continuous influx of fine-grained material was taking place.
The bulk of the rock is very fine-grained calcite, but the degree of recrystallization prevents identification of its origin. Much shallow-water fine-grained carbonate debris was probably carried downslope into the area, where it accumulated together with the tests of pelagic organisms.

\section{CONCLUSIONS}

The rather abrupt change in sedimentary regime, reflected in the sediments at Site 237 at about 400 meters from a higher sedimentation rate below to a lower rate above and from a shallower environment below to a deeper environment above indicates a change in the topographic situation of the site. This change occurred at approximately 57-58 m.y. B.P., a time which may mark the onset of rupture between the Chagos and Saya de Malha regions. Fisher et al. (1971) suggested that the Mascarene and Chagos-Laccadive plateaus were adjacent in pre-Miocene time prior to the start of the present episode of spreading from the median Central Indian Ridge (Figure 5). Results from Site 238, located in the Central Indian Ridge area near the southern end of the Chagos-Laccadive Ridge (Figure 1), show that sundering of the Chagos region from the Saya de Malha region took place as early as late early Oligocene (Chapter 9, this volume). It may have started even earlier, however, perhaps in late Paleocene time.

Fisher et al. (1971) suggested that the volcanic foundation of the Chagos-Laccadive Ridge and the segment of the Mascarene Plateau extending south-southwest from Saya de Malha was probably formed along the trace of the Chagos Fracture Zone, a Cretaceous and early Tertiary transform fault of major proportion, during a long pause in spreading (Figure 5). The age of the foundation and the petrologic affinity of that part of the Mascarene Plateau located between the granitic Seychelles Bank and the volcanic Saya de Malha Bank is still controversial, as the drilling at Site 237 failed to determine the age and nature of the basement. The configuration of the sea floor in this 
TABLE 4

Distribution of Benthonic Foraminifera in Paleocene and Lower Eocene Sediments at Site 237

\begin{tabular}{|c|c|c|c|c|c|c|c|c|c|c|c|c|c|}
\hline \multirow{5}{*}{ Epoch } & \multicolumn{3}{|c|}{ Eocene } & \multicolumn{10}{|c|}{ Paleocene } \\
\hline & Mid. & \multicolumn{2}{|c|}{ Early } & \multicolumn{7}{|c|}{ Late } & \multirow{2}{*}{\multicolumn{3}{|c|}{$\begin{array}{r}\text { Early } \\
\text { P2-P1 }\end{array}$}} \\
\hline & \multicolumn{2}{|c|}{ P.10-P.9 } & P7-P6 & \multicolumn{3}{|c|}{ P5-P4 } & & \multicolumn{3}{|c|}{ P3 } & & & \\
\hline & \multicolumn{3}{|c|}{ Assemblage 4} & \multicolumn{2}{|c|}{ Ass. 3} & \multicolumn{8}{|c|}{ Assemblage 2} \\
\hline & 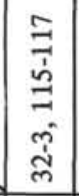 & 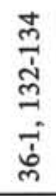 & 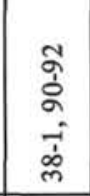 & 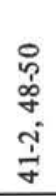 & $\begin{array}{l}\stackrel{\infty}{\exists} \\
\vec{b} \\
= \\
\tilde{j} \\
\dot{y}\end{array}$ & 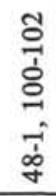 & 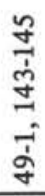 & 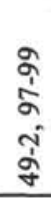 & 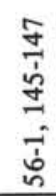 & 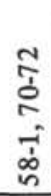 & 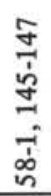 & 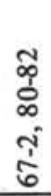 & $\begin{array}{l}5 \\
6 \\
6 \\
5 \\
5 \\
6\end{array}$ \\
\hline Ammodiscus incertus (d'Orbigny) & & & & & & & & & $\mathrm{X}$ & & $\mathrm{x}$ & & \\
\hline Angulogerina virginiana Cushman & & & & & & $\mathrm{X}$ & $\mathrm{X}$ & & & & & & \\
\hline Anomalina cubana Cushman and Bermudez & & & & & & & $\mathrm{X}$ & & & & & & \\
\hline Anomalina dorri aragonensis Nuttall & & $\mathrm{X}$ & & & & & & & & & & & \\
\hline Anomalina midwayensis (Plummer) & & & & $\mathrm{X}$ & & $\mathrm{X}$ & $\mathrm{x}$ & $\mathrm{x}$ & $\mathrm{X}$ & $\mathrm{x}$ & $\mathrm{X}$ & $\mathrm{X}$ & \\
\hline Anomalina welleri Plummer & & & & & & $\mathrm{X}$ & & & $\mathrm{X}$ & $\mathrm{X}$ & & $\mathrm{X}$ & \\
\hline Anomalina sp. & & & & & & & & & & & & & $\mathrm{X}$ \\
\hline Aragonina aragonensis (Nuttall) & $\mathrm{X}$ & $\mathrm{X}$ & & & & & & & & & & & \\
\hline Astacolus sp. & $\mathrm{X}$ & & & & & & & & & & & & \\
\hline Bathysiphon eocenicus Cushman and Hanna & & $\mathrm{X}$ & & & & & $\mathrm{X}$ & & $\mathrm{X}$ & & $\mathrm{X}$ & & \\
\hline Bolivina aff. B. anglica Cushman & & & $\mathrm{X}$ & & & & & & & & & & \\
\hline Bolivina crenulata Loetterle & & & & $\mathrm{X}$ & & & & & & & & & \\
\hline Bolivina midwayensis Cushman & & & & $\mathrm{X}$ & $\mathrm{X}$ & & $\mathrm{X}$ & & $\mathrm{X}$ & $\mathrm{X}$ & & & $\mathrm{X}$ \\
\hline Bolivina cf. B. nacheolensis (Cushman) & & & & & & & $\mathrm{X}$ & & $\mathrm{X}$ & & & & \\
\hline Bolivina spp. & & & & & & & & $\mathrm{X}$ & & & $\mathrm{X}$ & & \\
\hline Bulimina arkadelphiana midwayensis Cushman \& Parker & & & & & $\mathrm{X}$ & & & & & $\mathrm{X}$ & $\mathrm{X}$ & & \\
\hline $\begin{array}{l}\text { Bulimina aff. B. arkadelphiana mid wayensis } \\
\text { Cushman and Parker }\end{array}$ & & & & $\mathrm{X}$ & & & & & & & & & \\
\hline Bulimina cf. B. bradburyi Martin & $\mathrm{X}$ & & & $\mathrm{X}$ & & & & & & & & & \\
\hline Bulimina impendens Parker and Bermudez & $\mathrm{X}$ & & & & & & & & & & & & \\
\hline Bulimina cf, B. impendens Parker and Bermudez & & & & $\mathrm{X}$ & & & & & & & & & \\
\hline Bulimina spp. & & & & & $\mathrm{X}$ & & $\mathrm{X}$ & & & & & $\mathrm{X}$ & $\mathrm{X}$ \\
\hline Cibicides alleni Plummer & & & & & & & & & & & & $\mathrm{X}$ & $\mathrm{X}$ \\
\hline Cibicides blanpiedi Toulmin & & & & & & & & & & & & & \\
\hline Cibicides cf. C. blanpiedi Toulmin & & & & & & $\mathrm{X}$ & $\mathrm{X}$ & & & & & & \\
\hline Cibicides constrictus (Cushman) & & & & $\mathrm{X}$ & & & & $\mathrm{X}$ & & & & & \\
\hline Cibicides cf. C. spiropunctatus Galloway and Morey & & & $\mathrm{X}$ & & & & & & & & & & \\
\hline Citharina sp. & & & & $\mathrm{X}$ & & & & & $\mathrm{X}$ & $\mathrm{X}$ & $\mathrm{X}$ & & \\
\hline Clavulina aspera whitei Cushman and Jarvis & & & & $\mathrm{X}$ & $\mathrm{X}$ & & $\mathrm{X}$ & & & & & & \\
\hline Clavulina midwayensis (Cushman) & & & & & $\mathrm{X}$ & $\mathrm{X}$ & $\mathrm{X}$ & & & & & & \\
\hline Dentalina aculeata (d'Orbigny) & & & & & $\mathrm{X}$ & & & & & & & & \\
\hline Dentalina basiplanata Cushman & & & & & & & $\mathrm{X}$ & & & & & & \\
\hline Dentalina colei Cushman and Dusenbury & & $\mathrm{X}$ & & $\mathrm{X}$ & $\mathrm{X}$ & $\mathrm{X}$ & $\mathrm{X}$ & $\mathrm{X}$ & & & & & \\
\hline Dentalina cf. D. colei Cushman and Dusenbury & & & & & & & & & & & & & $\mathrm{X}$ \\
\hline Dentalina cf. D. communis (d'Orbigny) & & $\mathrm{X}$ & $\mathrm{X}$ & & & & & & $\mathrm{X}$ & $\mathrm{X}$ & & & \\
\hline Dentalina dusenburyi & $\mathrm{X}$ & & 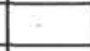 & & & & & & & & & & \\
\hline Dentalina eocenica Cushman & & & & & & $\mathrm{X}$ & $\mathrm{X}$ & & $\mathrm{X}$ & $\mathrm{X}$ & $\mathrm{X}$ & & $\mathrm{X}$ \\
\hline Dentalina pseudo-obliquistriata (Plummer) & & & & & & & $\mathrm{X}$ & & $\mathrm{X}$ & & & & \\
\hline Dentalina soluta Reuss & & & $\mathrm{X}$ & & & & $\mathrm{X}$ & $\mathrm{X}$ & & & & & \\
\hline Dorothia cf. D. bulletta Carsey & & & & & & & $\mathrm{X}$ & & & & & & \\
\hline Dorothia principensis Cushman and Bermudez & & & & $\mathrm{X}$ & & & & & & & & & \\
\hline Eponides aff. E. bollii Cushman and Renz & & & & $\mathrm{X}$ & & & $\mathrm{X}$ & & & & & & \\
\hline Eponides sp. & & $\mathrm{X}$ & $\mathrm{X}$ & & & & & & & & & & \\
\hline
\end{tabular}


TABLE 4 - Continued

\begin{tabular}{|c|c|c|c|c|c|c|c|c|c|c|c|c|c|}
\hline \multirow[b]{5}{*}{ Taxa } & \multicolumn{3}{|c|}{ Eocene } & \multicolumn{10}{|c|}{ Paleocene } \\
\hline & \multirow{2}{*}{\begin{tabular}{|l|} 
Mid. \\
P.10 \\
\end{tabular}} & \multicolumn{2}{|c|}{ Early } & \multicolumn{7}{|c|}{ Late } & \multirow{2}{*}{\multicolumn{3}{|c|}{$\begin{array}{c}\text { Early } \\
\text { P2-P1 }\end{array}$}} \\
\hline & & & P7-P6 & & & & & & P3 & & & & \\
\hline & \multicolumn{3}{|c|}{ Assemblage 4} & \multicolumn{2}{|c|}{ Ass. 3} & \multicolumn{8}{|c|}{ Assemblage 2} \\
\hline & 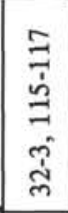 & 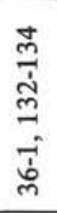 & 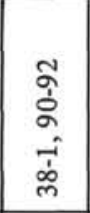 & 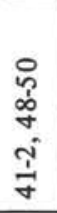 & $\begin{array}{l}\infty \\
\exists \\
\underline{J} \\
\exists \\
\tilde{J} \\
\dot{J}\end{array}$ & 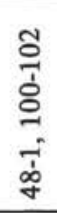 & 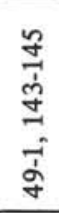 & 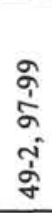 & $\begin{array}{l}\frac{y}{ \pm} \\
\dot{b} \\
\frac{1}{1} \\
-1 \\
\dot{b}\end{array}$ & 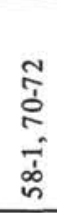 & 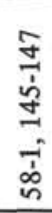 & 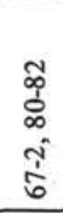 & $\begin{array}{l}5 \\
0 \\
0 \\
0 \\
5 \\
6\end{array}$ \\
\hline Fissurina orbignyana Sequenza & & & & & & & $\mathrm{X}$ & & & & & & \\
\hline Frondicularia aff. F. archiacana d'Orbigny & & & & & & & $\mathrm{X}$ & & & & & & \\
\hline Frondicularia midwayensis Cushman & & & & & & & & & & & & & $\mathrm{X}$ \\
\hline Frondicularia nacheolensis Cushman and Todd & & & & & & & $\mathrm{X}$ & & & & & & $\mathrm{X}$ \\
\hline Gaudryina laevigata Franke & & $\mathrm{X}$ & & $\mathrm{X}$ & $\mathrm{X}$ & & & & & & & & \\
\hline Gavelinella danica (Brotzen) & & & & $\mathrm{X}$ & $\mathrm{X}$ & $\mathrm{X}$ & $\mathrm{X}$ & $\mathrm{X}$ & & & & & $\mathrm{X}$ \\
\hline Glandulina laevigata (d'Orbigny) & & & & & $\mathrm{X}$ & $\mathrm{X}$ & & & & & & & \\
\hline Gyroidina globosa (Hagerow) & & & & $\mathrm{X}$ & $\mathrm{X}$ & $\mathrm{X}$ & $\mathrm{X}$ & $\mathrm{X}$ & $\mathrm{X}$ & $\mathrm{X}$ & & & \\
\hline Gyroidina nitida (Reuss) & & & & & $\mathrm{X}$ & & & & & & & & \\
\hline \multicolumn{14}{|l|}{ Gyroidina cf. G. nitida (Reuss) } \\
\hline Lagena acuticosta Reuss & & & & & & $\mathrm{X}$ & & & & & & & \\
\hline Lagena laevis (Montagu) & & & & & & $\mathrm{X}$ & & & & & & & \\
\hline Lagena cf. L. vulgaris Williamson & & & & & $\mathrm{X}$ & & & & & & & & \\
\hline Lenticulina arcuatostriata caroliniana Cushman & & & & $\mathrm{X}$ & $\mathrm{X}$ & & $\mathrm{X}$ & & & & & & $\mathrm{X}$ \\
\hline Lenticulina cf. L. arcuatostriata caroliniana Cushman & & & & & & $\mathrm{X}$ & & & $\mathrm{X}$ & & & & \\
\hline Lenticulina degolyeri Plummer & & & & & & & $\mathrm{X}$ & & & $\mathrm{X}$ & & & \\
\hline Lenticulina insulsa Cushman & & & & & & & $\mathrm{X}$ & & & $\mathrm{X}$ & $\mathrm{X}$ & & \\
\hline Lenticulina midwayensis (Plummer) & & & & & & & & & & & $\mathrm{X}$ & & \\
\hline Lenticulina velascoensis White & & & & & $\mathrm{X}$ & & & & & & $\mathrm{X}$ & & \\
\hline Lenticulina spp. & $\mathrm{X}$ & & & & & & & & & & & & \\
\hline Loxostomum applinae (Plummer) & & & & & & & $\mathrm{X}$ & & & & & & \\
\hline Marginulina dubia Neugeboren & & & & & & & & & & & & $\mathrm{X}$ & \\
\hline Marginulina cf. $M$. exima Terquem & & & & & $\mathrm{X}$ & & & & & & & & \\
\hline Marginulina glabra d'Orbigny & & & & & $\mathrm{X}$ & & & & & & & & \\
\hline Marginulina cf. M. glabra d'Orbigny & & & & & & & $\mathrm{X}$ & & & & & & \\
\hline Marginulina scitula Bornemann & & & & & & & $\mathrm{X}$ & $\mathrm{X}$ & & & & & \\
\hline Marginulina cf. $M$. scitula Bornemann & & & & & $\mathrm{X}$ & & & & $\mathrm{X}$ & & & & \\
\hline Marginulina spp. & & & $\mathrm{X}$ & & & & & & & & & & \\
\hline Marssonella oxycona (Reuss) & & & & & $\mathrm{X}$ & $\mathrm{X}$ & $\mathrm{X}$ & & & & & & $\mathrm{X}$ \\
\hline Marssonella cf. $M$. oxycona (Reuss) & & & $\mathrm{X}$ & & & & & & & & & & \\
\hline Melonis aff. M. planatus (Cushman and Thomas) & & & & & & & & & & $\mathrm{X}$ & & & \\
\hline Nodosaria affinis Reuss & & & & $\mathrm{X}$ & & & $\mathrm{X}$ & & & $\mathrm{X}$ & $\mathrm{X}$ & & $\mathrm{X}$ \\
\hline Nodosaria arundinea Schwager & & & & & & & & & & & & & $\mathrm{X}$ \\
\hline Nodosaria cf. $N$. ewaldi Reuss & & & & & & & & & $\mathrm{X}$ & & & & \\
\hline Nodosaria granti Plummer & & & & & & & & & & & $\mathrm{X}$ & & \\
\hline Nodosaria latejugata Gümbel & $\mathrm{X}$ & & & & & & $\mathrm{X}$ & & & & & & \\
\hline Nodosaria cf. $N$. latejugata Gümbel & & & & & $\mathrm{X}$ & $\mathrm{X}$ & & $\mathrm{X}$ & & & & & \\
\hline Nodosaria velascoensis Cushman & & & & & & & & $\mathrm{X}$ & & & & & \\
\hline Nuttallides truempyi (Nuttall) & $\mathrm{X}$ & $\mathrm{X}$ & & $\mathrm{X}$ & $\mathrm{X}$ & & & & & & & & \\
\hline Oridorsalis umbonatus Reuss? & & & & $\mathrm{X}$ & & & & & $\mathrm{X}$ & $\mathrm{X}$ & & & \\
\hline Osangularia culter (Parker and Jones) & & $\mathrm{X}$ & & & $\mathrm{X}$ & & $\mathrm{X}$ & $\mathrm{X}$ & & & & & \\
\hline Palmula reticulata Reuss & & & & $\mathrm{X}$ & & & $\mathrm{X}$ & & & & & & \\
\hline
\end{tabular}


TABLE 4 - Continued

\begin{tabular}{|c|c|c|c|c|c|c|c|c|c|c|c|c|c|}
\hline \multirow{3}{*}{$\begin{array}{r}\text { Epoch } \\
\text { ral Zone }\end{array}$} & \multicolumn{3}{|c|}{ Eocene } & \multicolumn{10}{|c|}{ Paleocene } \\
\hline & \multirow{2}{*}{\multicolumn{2}{|c|}{ 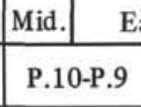 }} & Early & \multicolumn{7}{|c|}{ Late } & \multirow{2}{*}{\multicolumn{3}{|c|}{$\begin{array}{l}\text { Early } \\
\text { P2-P1 }\end{array}$}} \\
\hline & & & P7-P6 & & P5 & & & & P3 & & & & \\
\hline \multirow[t]{2}{*}{ Depth Assemblage } & \multicolumn{3}{|c|}{ Assemblage 4} & \multicolumn{2}{|c|}{ Ass. 3} & \multicolumn{8}{|c|}{ Assemblage 2} \\
\hline & 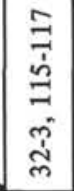 & 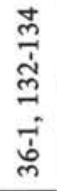 & $\begin{array}{l}\text { ন̃ } \\
\text { ूे } \\
\hat{\text { के }}\end{array}$ & 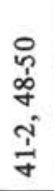 & $\begin{array}{l}\stackrel{\infty}{J} \\
\vec{b} \\
\exists \\
\tilde{y} \\
\tilde{y}\end{array}$ & 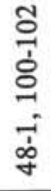 & 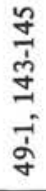 & $\begin{array}{l}\text { aे } \\
\text { aे } \\
\text { ஸे }\end{array}$ & 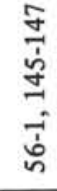 & 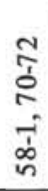 & 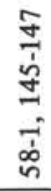 & 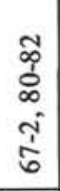 & 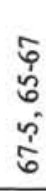 \\
\hline Palmula sp. & & & & & & $\mathrm{x}$ & & & & & & & \\
\hline Pleurostemella paleocenica Cushman & & & & & $\mathrm{X}$ & $\mathrm{X}$ & $\mathrm{X}$ & $\mathrm{X}$ & $\mathrm{X}$ & $\mathrm{X}$ & $\mathrm{X}$ & & $\mathrm{X}$ \\
\hline Pleurostemella aff. $P$. paleocenica Cushman & & $\mathrm{X}$ & & $\mathrm{X}$ & & & & & & & & & \\
\hline Pseudonodosaria manifesta (Reuss) & & & & & $\mathrm{X}$ & $\mathrm{X}$ & & & & & & & \\
\hline Pseudovalvulineria beccariformis (White) & & & & & $\mathrm{X}$ & & & & & & & & \\
\hline Pullenia coryelli White & & & & $\mathrm{X}$ & $\mathrm{X}$ & $\mathrm{X}$ & & & & & $\mathrm{X}$ & & \\
\hline Pullenia quinqueloba angusta Cushman and Todd & $\mathrm{X}$ & & & & & & & & & & & $\mathrm{X}$ & $\mathrm{X}$ \\
\hline Quadromorphina allomorphinoides (Reuss) & & & & & & & $\mathrm{X}$ & & & & & & \\
\hline Ramulina navarroana Cushman & & & & & $\mathrm{X}$ & & & & & & & & \\
\hline Saracenaria cf. S. trigonata (Plummer) & & & & & & & $\mathrm{X}$ & & & & & & \\
\hline Spiroplectammina mexiaensis Lalicker & & & & & $\mathrm{X}$ & & & & & & & & \\
\hline Spiroplectammina spectabilis Grzybowski & & & & $\mathrm{X}$ & & & & & & & & & $\mathrm{X}$ \\
\hline Spiroplectammina sp. & & $\mathrm{X}$ & & & & & & & & & & & \\
\hline Stilostomella hispidula Cushman & & & $\mathrm{X}$ & & & & & & & & & & \\
\hline Stilostomella kressenbergensis (Gümbel) & $\mathrm{X}$ & $\mathrm{X}$ & & & & & & & & & & & \\
\hline Stilostomella midwayensis (Cushman and Todd) & & & & & $\mathrm{X}$ & & & & & & & & \\
\hline Stilosteomella paleocenica (Cushman and Todd) & & $\mathrm{X}$ & & $\mathrm{X}$ & $\mathrm{X}$ & $\mathrm{X}$ & $\mathrm{X}$ & $\mathrm{X}$ & $\mathrm{X}$ & $\mathrm{X}$ & $\mathrm{X}$ & & \\
\hline Stilostomella spp. & $\mathrm{X}$ & & $\mathrm{X}$ & & & & & & & & & & \\
\hline Textularia plummerae Lalicker & & & & & & & $\mathrm{X}$ & & & & & & \\
\hline Trifarina adrena Cushman & $\mathrm{X}$ & & $\mathrm{X}$ & & & & & & & & & & \\
\hline Trifarina berberti Cushman and Renz & & & & $\mathrm{X}$ & & & & $\mathrm{X}$ & & & $\mathrm{X}$ & & $\mathrm{X}$ \\
\hline Vaginulina longiforma (Plummer) & & & & $\mathrm{X}$ & & $\mathrm{X}$ & $\mathrm{X}$ & & $\mathrm{X}$ & & & & $\mathrm{X}$ \\
\hline Vaginulina sp. & & & & $\mathrm{X}$ & & & & & & & & & \\
\hline Vaginulinopsis cf. V. mexicana & & $\mathrm{X}$ & & & & & & & & & & & \\
\hline
\end{tabular}

area during early Tertiary time is not fully known. It is clear, however, that at this time the area of Site 237 was not a reef-capped bank, as was expected prior to drilling, although there were nearby shoals from which slumped material was transported and redeposited in the pelagic sediments at Site 237. Between approximately 62 and 57 m.y. B.P. this site was probably not deeper than several hundred meters (perhaps $600 \mathrm{~m}$ or less) and was located at the base of a steep slope where slumped sediments could accumulate rapidly. It may therefore have been adjacent to some shallow-water structure which was probably in existence west of the Chagos Fracture Zone during this time. In late Paleocene time (ca 57 m.y. B.P.) a sudden sinking of the sea floor took place. The shoal portion of the Mascarene Plateau probably subsided below shelf depth, and slumping of shallow-water material into the area at Site 237 ceased. This deepening of Site 237 permitted lower bathyal benthonic faunas, similar to contemporaneous benthonic assemblages at Site 236 to the north, to develop in this area of the Mascarene Plateau. Pelagic sedimentation proceeded here during latest Paleocene and early Eocene at a reduced rate averaging $13 \mathrm{~m} / \mathrm{m}$.y. During this time interval, however, it slowed near the end of the Paleocene and in early Eocene during a time of nondeposition at Site 236. Sedimentation increased to approximately $17 \mathrm{~m} / \mathrm{m} . \mathrm{y}$. at the beginning of the middle Eocene.

The basal sediments at Site 237 are presently found at 2334 meters below the sea floor. If they were deposited in water depths of a few hundred meters, then the area has subsided about 2000 meters over the past 62 m.y. indicating a mean subsidence rate of $32 \mathrm{~m} / \mathrm{m} . \mathrm{y}$. This value is similar to the mean subsidence rate $(36 \mathrm{~m} / \mathrm{m}$.y.) obtained at Site 219 located at the northern end of the ChagosLaccadive Ridge (Figure 1). At the latter site, shallowwater sediments were deposited in a water depth of approximately 100 meters during late Paleocene at a rate of $70 \mathrm{~m} / \mathrm{m}$.y. The seabed began to sink probably toward the end of the Paleocene and after a period of nondeposition of 


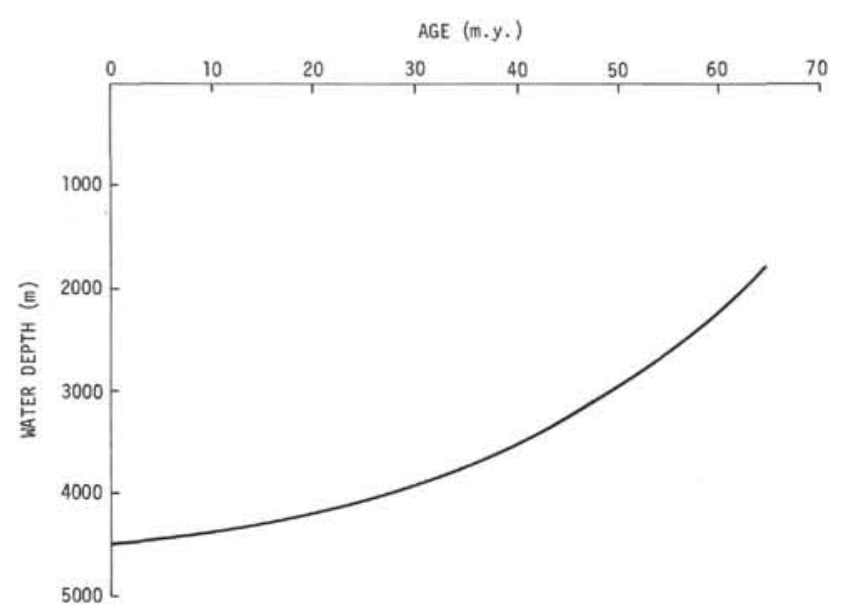

Figure 4. Depth as a function of age at Site 236 (derived from Sclater et al., 1971; and Berger, 1973).

about 5 m.y. spanning the Paleocene/Eocene boundary (as at Site 236), pelagic sediments were deposited at bathyal depths with a slower rate of $18 \mathrm{~m} / \mathrm{m} . \mathrm{y}$. Total subsidence was of the order of 2100 meters (Whitmarsh, Weser, et al., 1974, Chapter 3). There is, therefore, a remarkable synchroneity and similarity in the subsidence history of the Mascarene Plateau and the Chagos-Laccadive Ridge.

\section{ACKNOWLEDGMENTS}

The authors have benefited greatly, in the preparation of this report, from discussions with W. A. Berggren and R. C. Tjalsma (Woods Hole Oceanographic Institution), I. Premoli Silva (Universita di Milano), and R. L. Fisher (Scripps Institution of Oceanography). R. L. Fleisher (University of Southern California) kindly reviewed the manuscript. We would also like to thank L. Dmitriev (Academy of Sciences of the USSR) for his assistance in the preparation, aboard the Glomar Challenger, of the thin sections analyzed in this study.

We thank the management of Texaco Inc. and ELF-RE for permission to publish the article.

This study was supported under Oceanographic Section, National Science Foundation NSF Grand GA-34145 and represents Contribution No. 348, Department of Geological Sciences, University of Southern California.

\section{REFERENCES}

Bandy, O. L., 1960. General correlation of foraminiferal structure with environment: International Geological Congress, XXI Session, Norden, Party XXII, International Paleontological Union, p. 7-18.

1963. Larger living foraminifera of the continental borderland of southern California: Contrib. Cushman Found. Foram. Res., v. 14, pt. 4, p. 121-126. 1970. Upper Cretaceous-Cenozoic paleobathymetric cycles, eastern Panama and northern Colombia: Gulf Coast Assoc. Geol. Soc. Trans.,v. 20, p. 181-193.
Bandy, O. L. and Arnal. R. E., 1960. Concepts of foraminiferal paleoecology: Am. Assoc. Petrol. Geol. Bull., v. 44, p. 1921-1932.

Bandy, O. L. and Chierici, M. A., 1966. Depth-temperature evaluation of selected California and Mediterranean bathyal foraminifera: Marine Geol. v. 4, no. 4, p. 259-271.

Berger, W. H., 1972. Deep-Sea carbonates: Dissolution facies and age-depth constancy: Nature, v. 236, p. 392-395.

1973. Cenozoic sedimentation in the eastern tropical Pacific. Geol. Soc. Am., Bull., v. 84, p. 1941-1954.

Berggren, W. A., 1972. A Cenozoic time scale-some implications for regional geology and paleobiogeography: Lethaia, v. 15, p. 195-215. in press, a. Late Paleocene-early Eocene benthonic foraminiferal biostratigraphy and paleoecology of Rockall Bank: Micropaleontology.

, in press, b. Paleocene benthonic foraminiferal biostratigraphy, biogeography, and paleoecology of Libya (Sirte Basin) and Mali: Micropaleontology.

Berggren, W. A. and Phillips, J. D., 1971. Influence of continental drift on the distribution of the Tertiary benthonic foraminifera in the Caribbean and Mediterranean regions: Symposium on the Geology of Lybia, Faculty of Science, University of Lybia, Beirut, (Catholic Press), p. 263-299.

Douglas, R. G., 1973a. Benthonic foraminiferal biostratigraphy in the Central North Pacific, Leg 17, Deep Sea Drilling Project: In Winterer, E. L., Ewing, J. I., et al., Initial Reports of the Deep Sea Drilling, Volume 17: Washington (U.S. Government Printing Office), p. 607-672.

$1973 \mathrm{~b}$. Evolution and bathymetric distribution of Tertiary deep sea benthic foraminifera: Geol. Soc. Am., Abstracts with programs, v. 5, p. 603.

Cushman, J. A., 1925. An Eocene fauna from the Moctezuma River, Mexico: Am. Assoc. Petrol. Geol. Bull., v. 9, p. 298-303.

1926. The foraminifera of the Velasco Shale of the Tampico embayment: Am. Assoc. Petrol. Geol. Bull., v. 10, p. 581-612.

1951. Paleocene foraminifera of the Gulf Coastal Region of the United States and adjacent regions: U.S. Geol. Surv., Prof. Pap. 232, 75 p.

Cushman, J. A. and Renz, H. H., 1946. The foraminiferal fauna of the Lizard Springs Formation of Trinidad, British West Indies: Cushman Lab. Foram. Res., Sp. Pub. 18 , p. $1-48$.

Fisher, R. L., Johnson, G. L., and Heezen, B. C., 1967. Mascarene Plateau; western Indian Ocean: Geol. Soc. Am., Bull., v. 78, p. 1247-1266.

Fisher, R. L., Sclater, J. G., and McKenzie, D. P., 1971. The evolution of the Central Indian Ridge, Western Indian: Ocean: Geol. Soc. Am. Bull., v. 82, p. 553-562.

Folk, R. L., 1962. Spectral subdivision of limestone types. In Ham, W. H. (Ed.), Classification of carbonate rocks-a symposium: Am. Assoc. Petrol. Geol., Memoir 1, p. 62-84.

Gibson, J. M., 1973. Foraminiferal biostratigraphy of the Anita Formation, Western Santa Ynez Mountains, Santa Barbara County, California: M. S. Thesis, Univ. Southern California, Los Angeles, Calif.

Gibson, T. G. and Buzas, M. A., 1973. Species diversity: Patterns in modern and Miocene foraminifera of the eastern margin of North America: Geol. Soc. Am. Bull., v. 84 , p. $217-238$. 

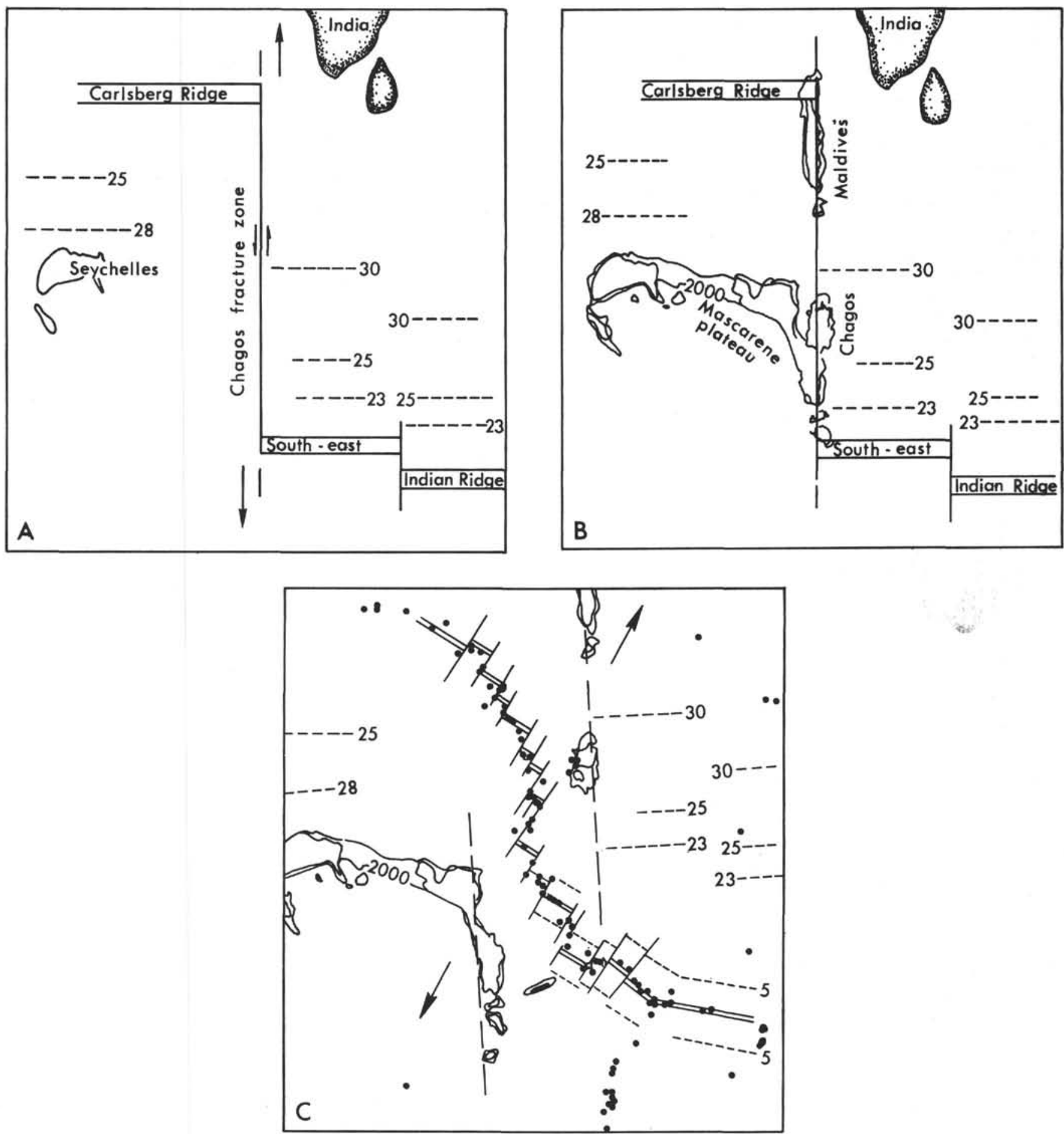

Figure 5. Schematic diagram of the Central Indian Ocean. 
Grimsdale, T. F. and Morkhoven, F. P. C. M. van, 1955. The ratio between pelagic and benthonic foraminifera as a means of estimating depth of deposition of sedimentary rocks: World Petrol. Congr., 4th, Proc., Sec. 1/D, p. $473-490$.

Heirtzler, J. R., Dickson, G. O., Herron, E. M., Pitman, W. C., and Le Pichon, X., 1968. Marine magnetic anomalies, geomagnetic field reversals and motions of the ocean floor and continents: J. Geophys. Res., v. 73, p. 2119-2136.

Kellough, G. R., 1959. Biostratigraphic and paleoecologic study of Midway foraminifera along Tehnacana Creek, Limestone County, Texas: Gulf Coast Assoc. Geol. Soc. Trans., v. 9, p. 147-160.

1965. Paleoecology of the foraminiferida of the Wills Point Formation (Midway Group) in northeast Texas. Gulf Coast Assoc. Geol. Soc. Trans., v. 15, p. 73-153.

McKenzie, D. and Sclater, J. G., 1971. The evolution of the Indian Ocean since the Late Cretaceous: Geophys. J. Roy. Astron. Soc., v. 15 , p. 437-528.
Plummer, $\mathrm{H}$ ग., 1926. Foraminifera of the Midway Formation in Texas: Univ. Texas Bull., v. 2644, p. 3-206.

Porrenga, D. H., 1967. Glauconite and chamosite as depth indicators in the marine environment: Marine Geol., v. 5, p. 495-501.

Sclater, J. G., Anderson, R. N., and Bell, M. L., 1971. Elevation of ridges and the evolution of central eastern Pacific: J. Geophys. Res., v. 76, p. 7888-7915.

Theyer, F., 1971. Size-depth variation in Cyclammina cancellata Brady, Peru-Chile Trench area: Antarctic Res. Ser. (Oceanology I), v. 15, p. 309-313.

White, M. P., 1928, Some index foraminifera of the Tampico Embayment area of Mexico: J. Paleo., v. 2, p. 280-317.

1929. Some index foraminifera of the Tampico Embayment area of Mexico: J. Paleo., v. 3, p. 30-58.

Whit marsh, R. B., Weser, O. E., et al., 1974. Initial Reports of the Deep Sea Drilling Project, Volume 23: Washington (U.S. Government Printing Office). 


\section{PLATE 1}

Figure 1 Sparse biomicrite with radiolarians. Sample 237-37-2 (15), $\times 130$.

Figure 2 Sparse biomicrite with planktonic foraminifera and radiolarians. Morozorella cf. subbotinae (Morozova). Sample 237-38-1 (13), X63.

Figure 3 Sparse biomicrite with planktonic foraminifera and radiolarians. Morozorella gr. velascoensis (Cushman). Sample 237-41-2 (13), X63.

Figure $4 \quad$ Morozorella aequa (Cushman and Senz). Sample 237. 44-1 (12), $\times 130$.

Figure 5 Packed biomicrite with planktonic foraminifera. Planorotalites ehrenberghi (Bolli). Morozorella gr. pusilla (Bolli). Sample 237-45-2 (6). X44.

Figure $6 \quad$ Planorotalites gr. ehrenberghi (Bolli). Sample 237. 46-2 (6), $\times 130$.

Figure $7 \quad$ Packed biomicrite. Valrulinid. Sample 237-47-2 (2), X44.

Figure $8 \quad$ Morozorella gr. velascoensis (Cushman). Sample 237. 47-2(2), $\times 130$.

Figure 9 Morozorella angulata (White). Sample 237-47-2 (2), $\times 130$.

Figure $10 \quad$ Morozorella gr. velascoensis (Cushman). Sample 237. 48-1 (4), X130.

Figure 11, 12 Packed biomicrite with larger foraminifera, bryozoan, mollusc, and echinoderm debris. Discocyclina seunesi Douvillé, Ranikothalia bermudezi (Palmer). Sample 23748-2 (120), X39. 
PLATE 1
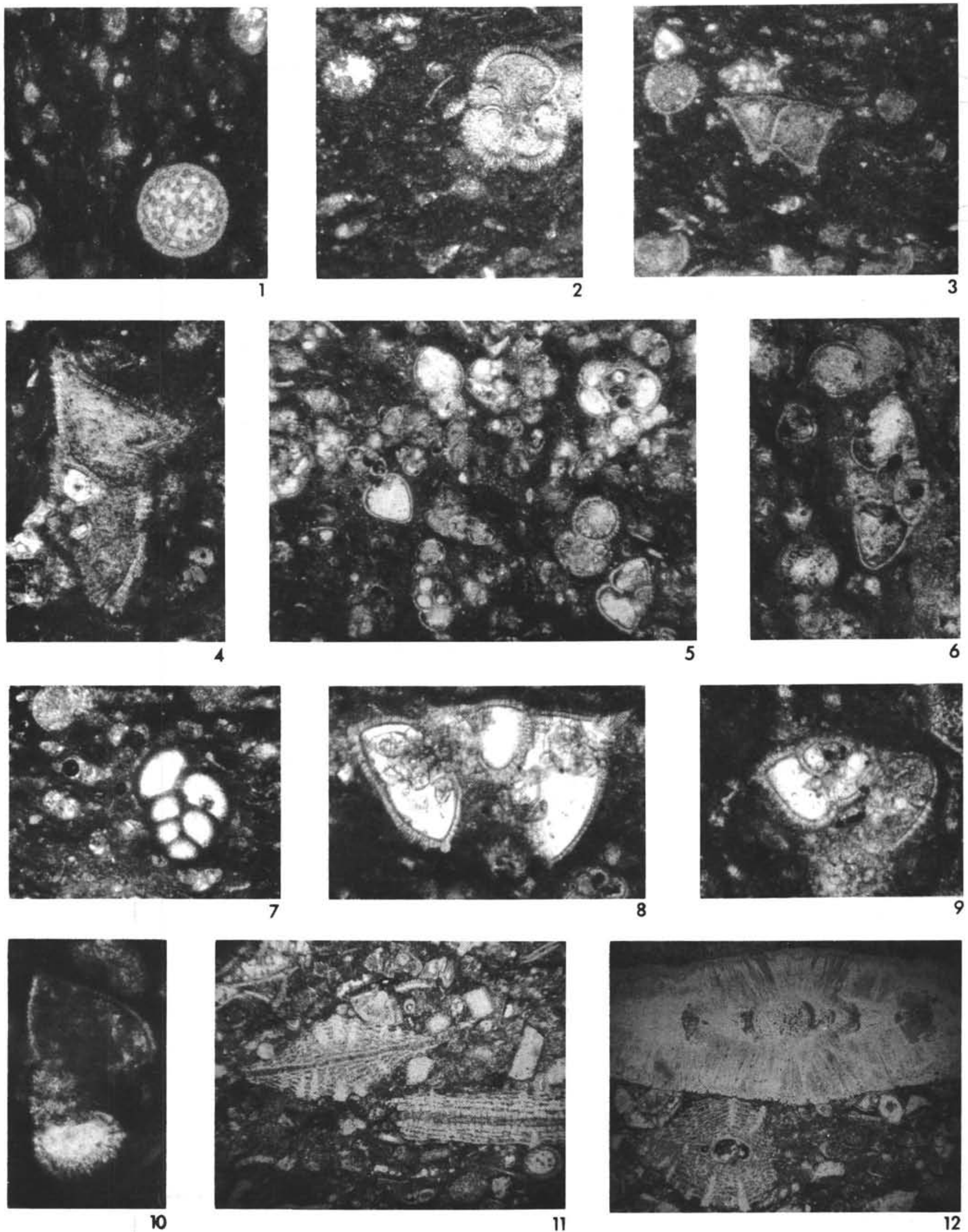


\section{PLATE 2}

Figure 1 Morozorella angulata (White). Sponge spicule. Sample 237-50-1 (13), X130.

Figure 2 Sparse biomicrite with radiolarians and planktonic foraminifera. Sample 237-51-2 (10), X44.

Figure 3 Sparse biomicrite. Pellets. Sample 237-51-2 (10), X44.

Figure $4 \quad$ Morozorella gr. velascoensis (Cushman). Sample 237. $512(10), \times 130$.

Figure 5 Morozorella cf. angulata (White). Sample 237-52-1 (13), $\times 130$.

Figure 6 Planorotalites cf. compressa (Plummer). Sample 237. 54-1 (6), $\times 130$.

Figure 7 Packed biomicrite with planktonic foraminifera. Lenticulina sp. Sample 237-54-1 (6), X44.

Figure 8 Archaeolithothamnium. Mollusc and echinoderm debris. Sample 237-58-1 (95), X44.

Figure 9 Planorotalites cf. compressa (Plummer). Sample 237. $61-1(13), \times 130$.

Figure $10 \quad$ Morozorella inconstans (Subbotina). Glauconite grains. Sample 237-64-2 (7), X130.

Figure 11 Sparse biomicrite. Morozorella inconstans (Subbotina). Sample 237-61-1 (13), X130.

Figure 12 Fossiliferous micrite. "Globigerinid." Sample 237. $67-3(7), \times 130$. 
PLATE 2
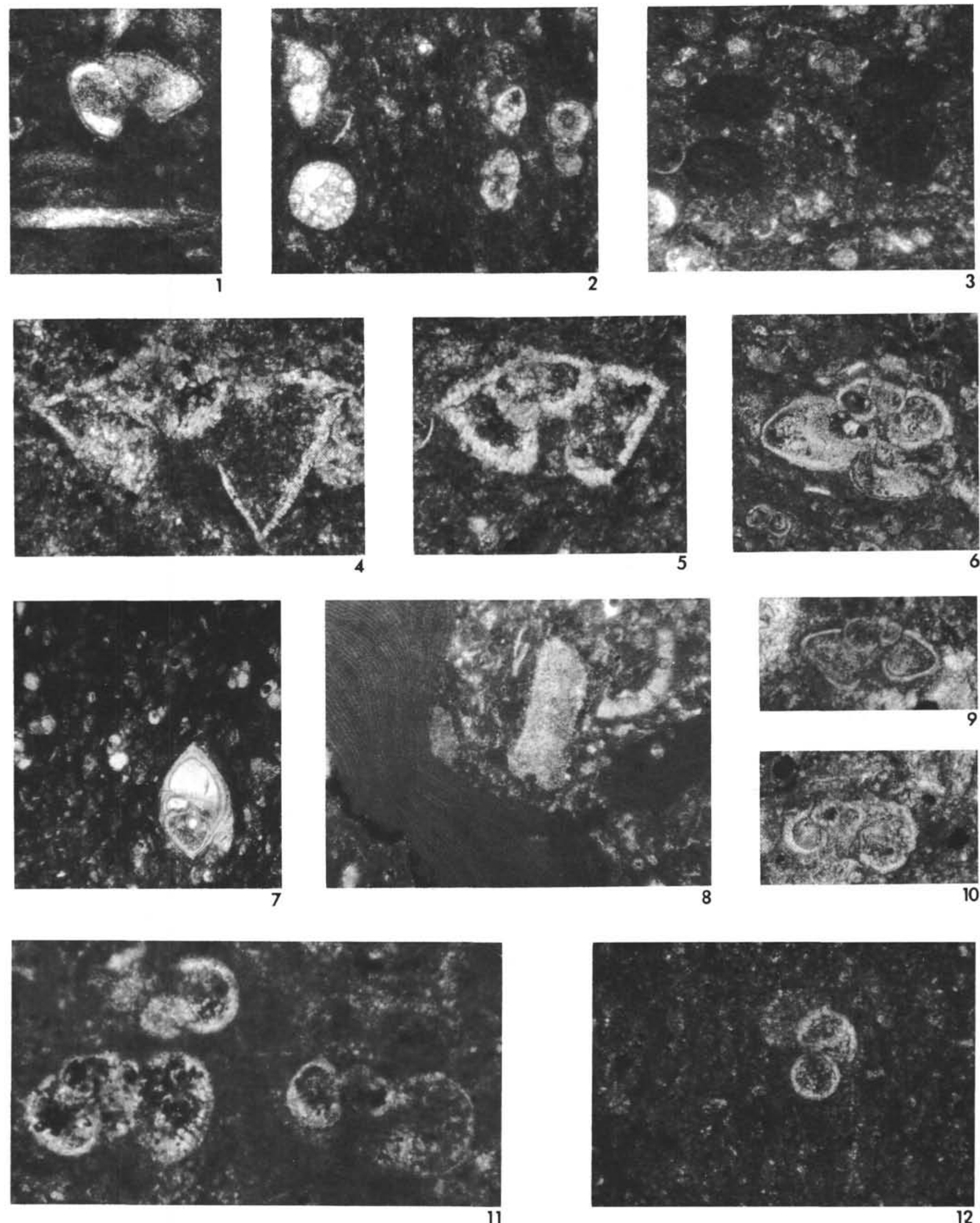


\section{PLATE 3}

Paleocene, Site 236

Figure 1

Figure 2

Figure 3

Figure 4

Figure 5

Figure 6

Figure 7

Figure 8

Figure 9

Figure 10

Figure 11

Figure 12

Figure 13

Figure 14

Figure 15

Figure 16

Figure 17

Figure 18

Figure 19

Figure 20
Marssonella oxycona (Reuss, 1860). Sample 33-3, $105-107 \mathrm{~cm} . \times 50$.

Gaudryina laerigata Franke, 1914. Sample 33-3, $105-107 \mathrm{~cm} . \times 50$.

Spiroplectammina excolata (Cushman, 1926). Sample $33-3,105-107 \mathrm{~cm} \times 100$.

Spiroplectammina spectabilis Gryzbowski, 1898. Sample 33-1, 107-109 cm X100.

Aragonia valascoensis (Cushman, 1926). Sample 33-3, $105-107 \mathrm{~cm} \times 55$.

Bolivinoides delicatula Cushman, 1927. Sample 33-3, $105-107 \mathrm{~cm} \times 100$.

Melonis planatus (Cushman and Thomas, 1930). Sample 33-3, 105-107 cm X110.

Palmula delicatissima (Plummer, 1926). Sample 33-1, $107-109 \mathrm{~cm} \times 100$.

Pseudogloboro florealis (White, 1928). Sample 33-1, $107-109 \mathrm{~cm} \times 50$.

Gyroidina depressa (Alth, 1850). Sample 33-3, 105 $107 \mathrm{~cm}$.

a. Umbilical view $\times 100$

b. Apertural view $\times 100$.

Osangularia aff. O. culter (Parker and Jones, 1865). Sample 33-3, 105-107 cm $\times 50$.

Loxostomum trinitatensis Cushman and Renz, 1946. Sample 33-1, 107-109 cm. X100.

Nuttallides truempyi (Nuttall, 1930). Sample 33-3, $105-107 \mathrm{~cm}$.

a. Umbilical view $\times 100$.

b. Dorsal view $\mathrm{X} 100$.

Pullenia coryelli White, 1929. Sample 33-1, 107-109 $\mathrm{cm} . \times 100$.

Bulimina velascoensis (Cushman, 1925). Sample 33-1, $107-109 \mathrm{~cm} \times 50$.

Gyroidina girardana (Reuss, 1851). Sample 33-1, $107-109 \mathrm{~cm}$. $\times 100$.

Lenticulina velascoensis White, 1928. Sample 33-3, $105-107 \mathrm{~cm} . \times 100$.

Gavelinella aff. G. danica (Brotzen, 1940). Sample 33-3, 105-107 cm. X100.

Pseudovalvulineria beccariiformis (White, 1928). Sample 33-3, 105-107 cm $\times 100$.

Gyroidina globosa (Hagenow, 1842). Sample 33-1, $107-109 \mathrm{~cm} \times 100$. 


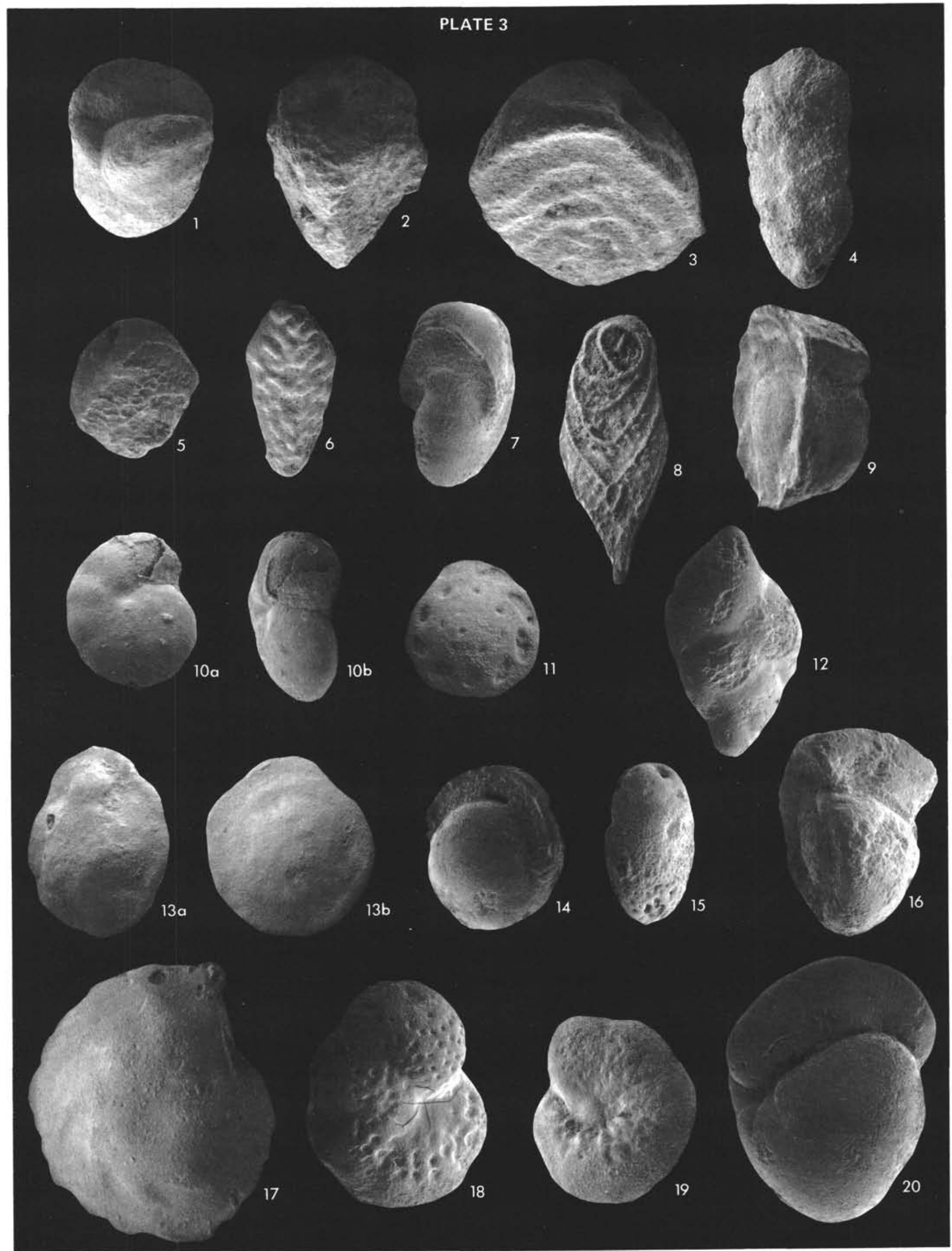




\section{PLATE 4}

Paleocene and Early Eocene, Sites 236 and 237

Figure 1 Anomalina uelleri (Plummer, 1926). Sample 236-33-1, $107-109 \mathrm{~cm}$.

a. Umbilical view $\times 100$.

b. Apertural view $\times 100$.

Figure 2 Clavulina aspera Cushman, 1926. Sample 237-49-1, $143-145 \mathrm{~cm} . \times 50$.

Figure 3 Pleurostemella paleocenica Cushman, 1947. Sample 237-67-5, 65-67 cm. X100.

Figure 4 Bolivina midwayensis Cushman, 1937. Sample 237. $56-1,145-147 \mathrm{~cm} \times 100$.

Figure $5 \quad$ Bulimina arkadelphiana midwayensis Cushman and Parker, 1936. Sample 237-49-1, 143-144 cm X100.

Figure 6 Vaginulina longiforma (Plummer, 1926). Sample 237$67-5,65-67 \mathrm{~cm} \times 50$.

Figure 7 Palmula reticulata (Reuss, 1851). Sample 237-44-2, $116-118 \mathrm{~cm} \times 100$.

Figure $8 \quad$ Aragonia aragonensis (Nuttall, 1930). Sample 236$31-2,70-72 \mathrm{~cm} \times 100$.

Figure 9 Anomalina dorri aragonensis Nuttall, 1930. Sample 236-31-2, 70-72 cm X50.

Figure $10 \quad$ Pleurostomella aff. P. paleocenica Cushman, 1947 (robust form). Sample 236-29-1, 80-82 cm. X100.

Figure 11 Bulimina sp. Sample 236-29-1, 80-82 cm. $\times 100$.

Figure $12 \quad$ Nuttallides truempyi (Nuttall, 1930). Sample 23629-1, 80-82 cm. X100. 

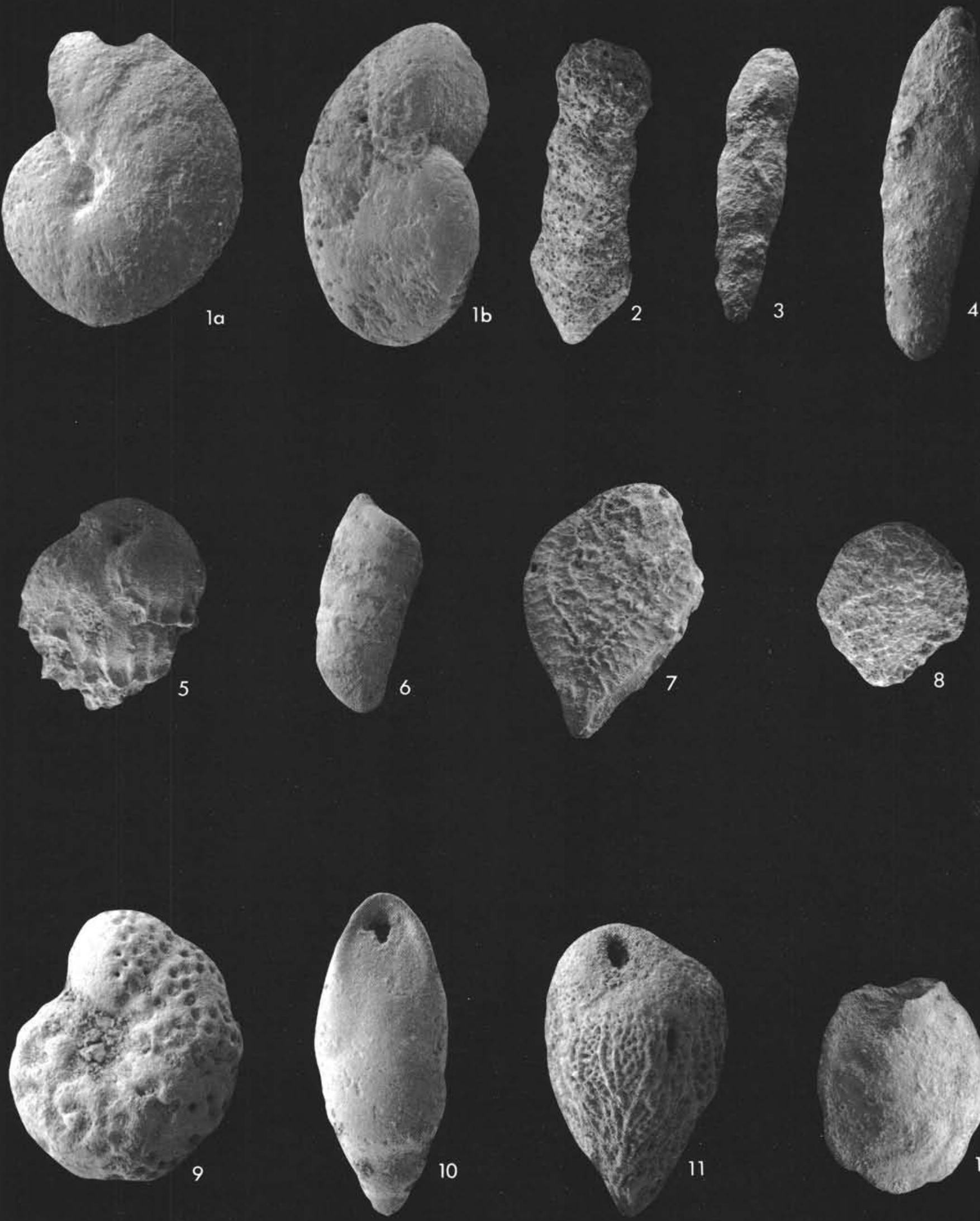

10

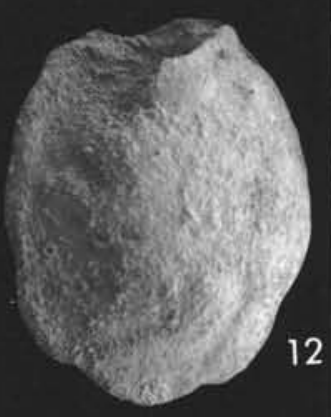

